
\title{
BResarch Soute \\ Geo-Environmental investigation of Sahure pyramid complex, Abusir Archeological site, Giza, Egypt
}

Abdelrhman Muhamed Fahmy Sayed Ahmed ( $\nabla$ abdelrhmanmuhammedfahmy@cu.edu.eg ) https://orcid.org/0000-0001-7090-082X

\section{Fatma Muhamed Helmy}

Cairo University

Research article

Keywords: Abusir, archaeological area, Sahure pyramid, geo-environment, geo chemistry, decay, sandy limestone, meteorological, petro-physical/physical properties, petrological

Posted Date: March 15th, 2021

DOI: https://doi.org/10.21203/rs.3.rs-282899/v1

License: (c) (1) This work is licensed under a Creative Commons Attribution 4.0 International License. Read Full License 


\title{
Geo-Environmental investigation of Sahure pyramid complex, Abusir Archeological site, Giza, Egypt
}

\author{
Abdelrhman Fahmy 1*, Fatma.M.Helmy ${ }^{2}$ \\ 1 Department of Earth Sciences, Faculty of Sciences, University of Cadiz, Campus Río San Pedro, \\ 11510 Puerto Real, Cadiz, Spain \\ ${ }^{2}$ Conservation Department, Faculty of Archaeology, Cairo University,12613, Giza, Egypt \\ * Correspondence: abdelrhmanmuhammedfahmy@gmail.com, Tel: 00201002058457 / +34655138576
}

\begin{abstract}
Abusir is the name of an elaborate burial area, dotted with 19 pyramids other temples, stretching on the western side of the Nile from the south of the Giza Plateau to the northern rim of Saqqara. It seems to have been created as the resting site for the Pharaos dated from 2494 to 2345 BC. The name Abusir, originally spoken as Busiri, means" temple of Osiris". Over time, the name has become so popular, that more than 60 villages now carry this name. But only one is the archaeological site. This paper does not refer to all of the Abusir archaeological area, but focuses one of its most important sites: Sahure pyramid, one of Egypt's little known, but heavily damaged treasure. One of the highlights of the relevant research is the discovery of a piece of cement (Basaltic mortar/concrete), which consists of several materials and which is harder than any cement produced today and detection of a clear and significant Anorthite mineral (Plagioclase) in the mortar sample which had been proven by XRD, XRF (analysis) and Polarized light microscope (investigation). The main objectives of this paper are 1) to reveal and identify the construction materials of the pyramid and the construction of the pyramid,2) to evaluate the durability and vulnerability of the Ancient construction materials of Sahure pyramid,3) to compare the decayed patterns of the different construction materials, 4) to study the pyramid building materials from geological, meteorological, geochemical, petrological and petrophysical point of view, and 5) to present a proposal for scientific conservation and protection of the pyramid. Laboratories and field studies have been carried out by researchers from various countries to investigate and understand the problems of the pyramid leading to the final results which confirmed the impact of the geo environment conditions on the structural and engineering stability of the pyramid.
\end{abstract}

Keywords: Abusir; archaeological area; Sahure pyramid; geo-environment; geo chemistry; decay; sandy limestone; meteorological; petro-physical/physical properties; petrological

\section{Introduction}

Abusir is located in the southern direction of Giza plateau and north Saqqara archeological site, it is considered one of the most enriched archaeological sites of Memphis necropolis (A.Nour Eldein.2007)[1]. The ancient name of Abusir is called busiri "the house or temple of the Osiris". Of the sixty or so villages named Abusir in Egypt only one is an archaeological site of first-class importance; the Abusir as shown in figure 1 with the cemetery of Fifth Dynasty kings. The history of Abusir is much older than the Fifth Dynasty, in the Early Dynastic Period; Abusir became a rapidly growing cemetery. In south Abusir, close to the Early Dynastic cemetery in north Saqqara, a rich, upper middle class cemetery dating from the First and Second Dynasty was revealed at the beginning of the twentieth century by a German archaeological expedition directed by Hans Bonnet. Three decades later another Early Dynastic (Verner, M.2007) [2].Abusir as shown in Figure 2 was the only a short lived cemetery with the pyramid complexes of three kings of the fifth dynasty,1)Sahure, 2) NeferirKare and 3) Niuserre (Verner, M.2012)[3]. In 2015, Abusir had been 
scanned and modeled by the Czech Institute of Egyptology and Japanese team (Yukinori Kawae, et al.2015)[4].

Two Italian scholars, Vito Maragioglio and Celeste Rinaldi, contributed to the researches on Abusir too. They surveyed the site providing rich information on the Abusir pyramids and improving the plans of the monuments (Vernern,M.2002)[5]. At the same time, the beginning of 1960s, a Czech archaeological expedition started to work in this area. After a geophysical survey of the whole site, the Czech team transferred, in the mid-1970s, its researches to the not yet investigated southern area of the necropolis. The Czech Institute of Egyptology is continuing excavations at Abusir, the team led by Miroslav Bárta (Czech Institute of Egyptology) [6].In 1960 Kenneth explained the weathering of great pyramid and identified four various of limestone used in building of great pyramid such as grey hard dense limestone, grey soft limestone, grey shaly limestone and yellow limy shaly sandstone(K.O.Emery.1960)[7]. Hanafy Holail presented a diagnosis study of the middle Eocene "nummulite bank" of Giza Pyramid plateau and explained that the early diagentic alteration of the rock matrix was followed by partial to complete dolomitization of the limestone matrix and nummulite grains (Hanafy.M.Holail.1994)[8]. Frank Zalewski studied and give us opportunity to see the construction materials of great pyramid in his study about petrography observations of the building stones of great pyramids(Zalewski,F.2017)[9]. Abusir is a sophisticated archaeological site with adequate and different kind of building materials for pyramids and the preservation state of this is site is so poor especially Sahure pyramid which suffered a lot from environmental impacts in static state and dynamically from earthquakes and wind loads. The scopes of this paper are 1) to reveal and identify the construction materials of the pyramid and the construction of the pyramid, 2) to evaluate the durability and vulnerability of the Ancient construction materials of Sahure pyramid throughout comparing the decayed patterns of the different construction materials studying the pyramid building materials from geological, meteorological, geochemical, petrological and petro-physical point of view, and 3) to present a proposal for scientific conservation and protection of the pyramid. The importance of this study is to make hazard analysis for the construction materials of the pyramid which carried out by using many tools such as XRD, XRF, optical microscope, Polarizing microscope and physical properties leading to adequate investigation for the environmental impacts on the construction materials of the pyramid and their behaviors towards many environmental factors.
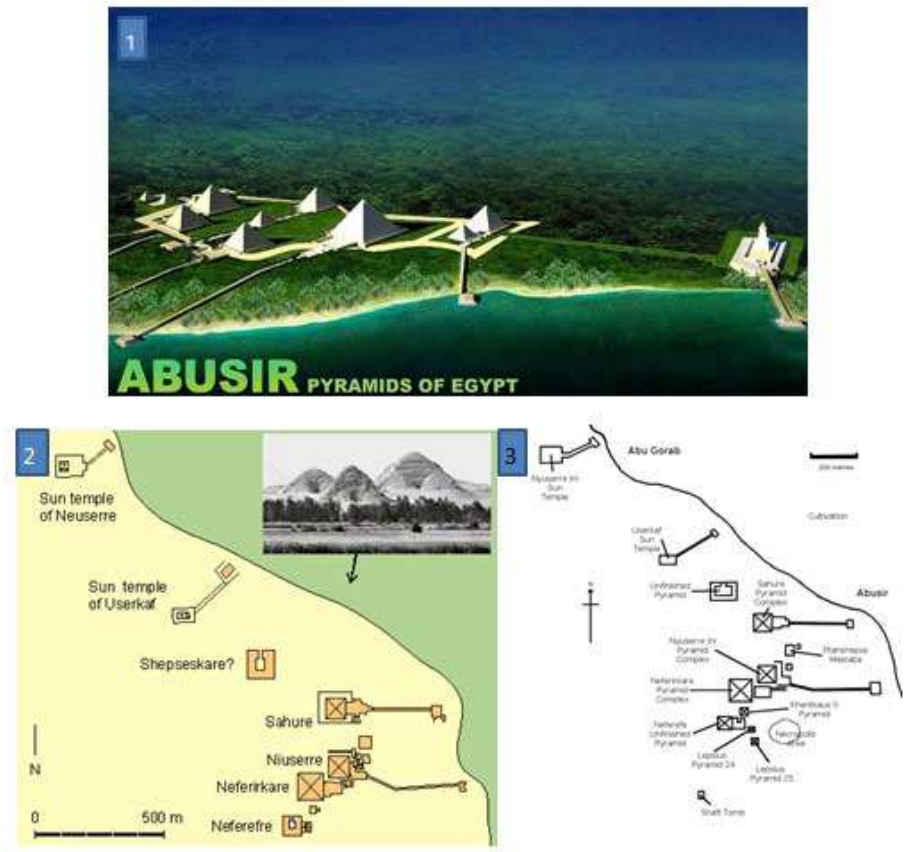

Figure.1. The general map of Abusir archaeological site and its pyramids. From, 75 1.http://thehiddenrecords.com/sphinx, 


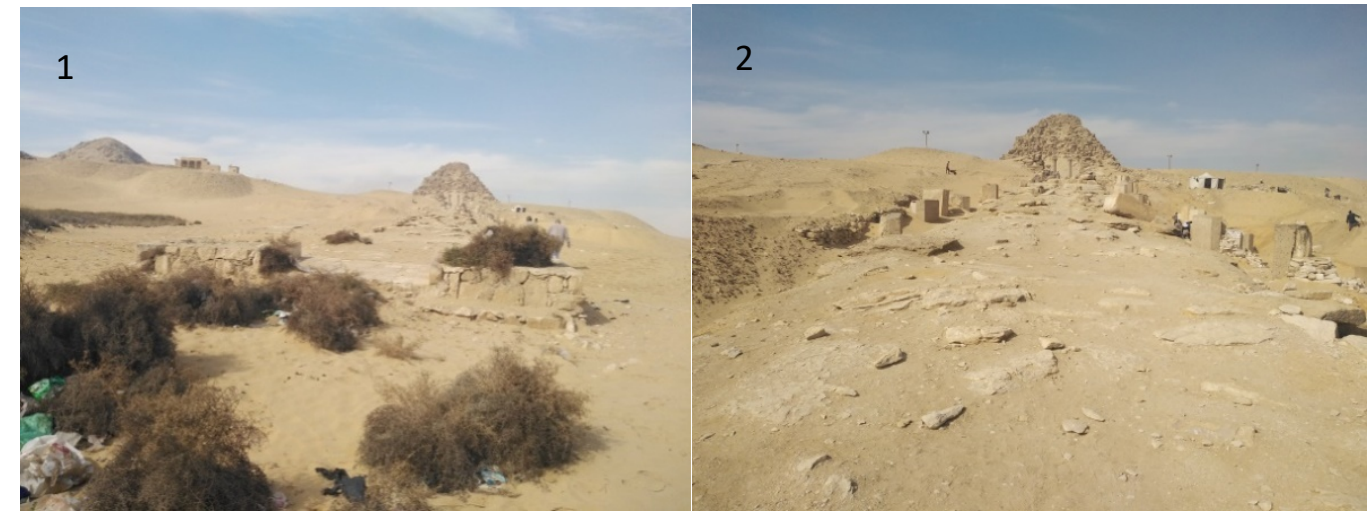

Figure.2. 1,2 General view for Abusir archaeological site and Sahure pyramid from valley temple of

\section{Sahure pyramid}

The pyramid of Sahure located on hill and the distance from the valley temple which was adjacent to Nile about 20 meters figure 3(verner,M.20001)[10].The burial pyramid of Sahure is relatively small, only having a base of around seventy-eight meters and rising to a height of fortyseven meters. However, it was built using better quality stone of more diverse types than the pyramids of the fourth dynasty (verner,M.20001)[10]. It is thought that the pyramid was built on a base of at least two layers of limestone, but the base has not been excavated so this is simply an educated guess based on comparisons with other structures from the same area. The pyramid core was composed of six steps figure 4 of limestone held together with mud mortar with an entrance to the north and it was cased in fine white limestone from Maasara(verner,M.20001)[10].

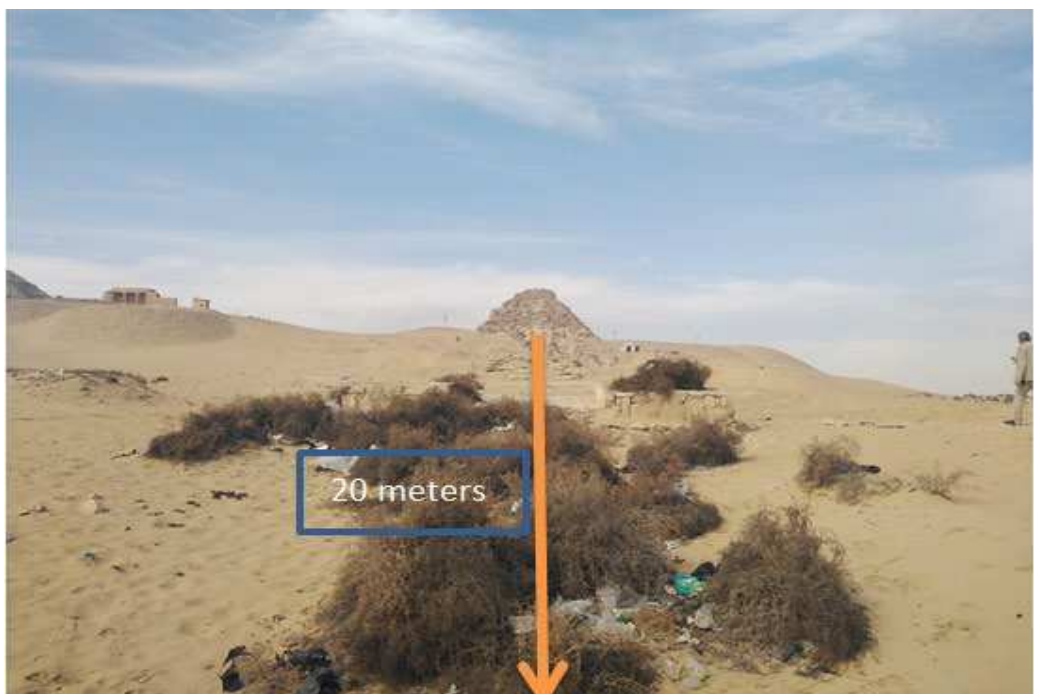

Figure.3. The elevation level shows the distance between the pyramid and the valley. 


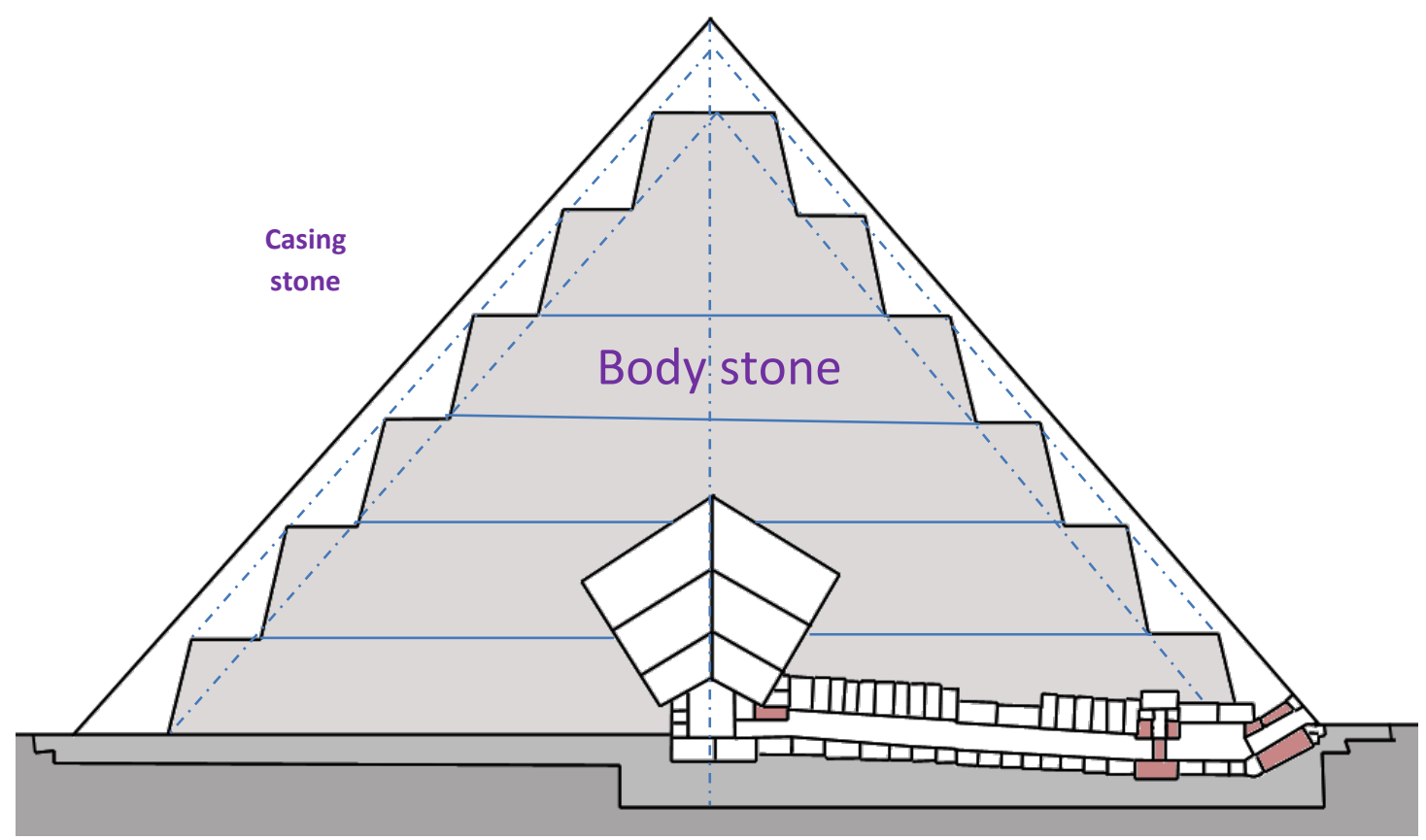

Figure.4. Cross section of Sahure's pyramid, white: white Fossiliferous limestone from Tura quarry (casing stone), red: granite, body of the pyramid: Laminated sandy argillaceous limestone (marl),

Sahure's pyramid was constructed in enriched and various kinds of stones for construction. The casing stone of the pyramid is massive like the casing stones at Neferefre's (unfinished pyramid) or great pyramid and the measurements of blocks in comparison with Neferefre's unfinished pyramid measured as $5 \mathrm{~m} \times 5.5 \mathrm{~m} \times 1 \mathrm{~m}$ (verner,M.2001)[10]. The inner chambers were similarly cased, but using significantly smaller blocks(Verner,M.1994)[11].The core of the pyramid was packed with a rubble fill of limestone chips, pottery shards, and sand, with clay mortaring (verner,M.2001)(Verner,M.1994)(Lehner, M. 2008) [10,11,12].This technique of construction is less cost and less efforts and less time but the casing stone constructed by utilizing high quality limestone from Tura and Massara quarries (Verner,M.1994)[11].

Because of the poor circumstances of the pyramid, the layout of the pyramid is slightly not measured excellently (verner,M. 2001)[10]. The pyramid had a base length of $78.5 \mathrm{~m}$ and $48 \mathrm{~m}$ high figure 5(verner,M. 2001)[10].The architects made a notable error in demarcating the base, causing the southeast corner of the pyramid to extend $1.58 \mathrm{~m}$ too far east (verner,M. 2001)[10]. The pyramid is surrounded by a limestone which used for paving, except for where the mortuary temple stood and paved by using basalt, and is accessed from the temple's north and south sides, enclosing the courtyard is a tall, rounded enclosure wall 3.15m thick (Borchardt, L. 1910)[13].

The pyramid substructure access is found slightly above ground on the pyramid's north face (verner,M.2001)[10].A short descending corridor lined with granite leads into a vestibule(Lehner, M. 2008)[12], beyond which the route is guarded by a pink granite portcullis(verner,M. 2001)[10],either side of which the walls are lined with granite (Eswards I. 1975) [14],the descending corridor is 4.25 meters long with a slope of $24^{\circ} 48^{\prime}$, and has a passage $1.27 \mathrm{~m}$ wide and $1.87 \mathrm{~m}$ high(Lehner, M. 2008) (Stadelmann, R. 1985) [12,15].The corridor following is lined with limestone begins with a slight ascent before becoming horizontal land lined with granite(Lehner, $M$. 2008)[12].The ascending portion is $22.3 \mathrm{~m}$ long with a slope of $5^{\circ}$, whilst the horizontal section is 3.1m long (Stadelmann, R. 1985) [15].

The reconstruction of substructure accurately was so hard word as the corridors so damaged from the thieves and the loads(verner,M. 2001)[10].The burial chamber is a single chamber measured to be $12.6 \mathrm{~m}$ east-west and $3.15 \mathrm{~m}$ north-south(verner,M. 2001)(Lehner, M. 2008) (Edwards, I. 1975)[10,12,14] 


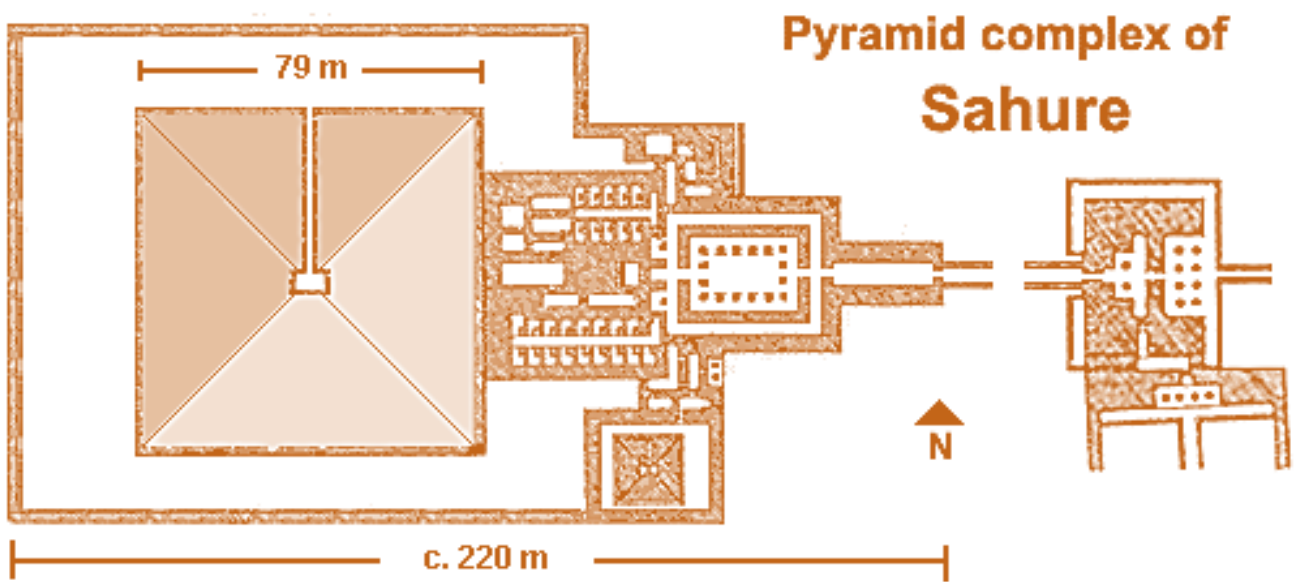

Figure.5. Layout of Sahure pyramid, after

Lithologically, Abusir geological formations are the Late Eocene Maadi limestone, clay limestone and marls (tafla) figure 6. The upper member of the Maadi Formation, Giran el Ful, is developed mostly as porous brown sandy limestone tempestitefacies (Barta, M.2015) [16]. With comparison with Saqqara area which is as adjacent neighbor to Absuir archaeological site bedrock comprises two different litho-topes, limestone/argillaceous limestone and marlstone. The AIR of the argillaceous limestone ranges from $14-19 \%$, whereas in the marlstones it is $43-53 \%$.Binocular microscope examination of the AIR revealed that clay with subordinate sand plus a small amount of gypsum are the dominant components. The AIR of the argillaceous limestone is composed of 86$91 \%$ clay, $5-9 \%$ sand and 3-5\% gypsum, whilst that of the marlstones is $78-84 \%$ clay, $9-13 \%$ sand and $6-9 \%$ gypsum (Akarish, A. and Shoeib, A. 2011)[17].

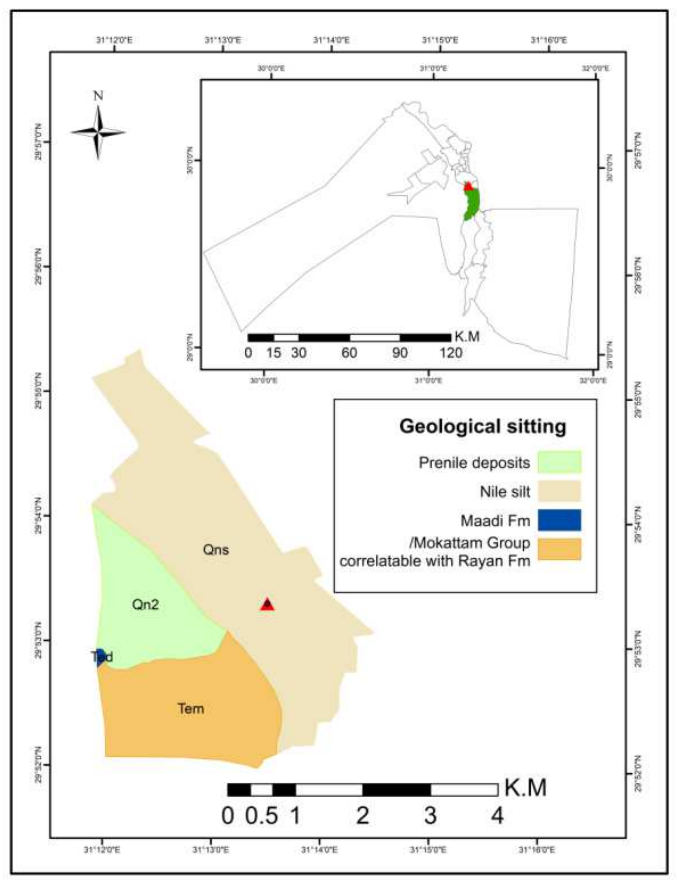




\section{Geo-environmental impact on Sahure pyramid}

The area of Abusir is neglected and affected by plenty of geo-environmental reasons such as the climate and surrounding environmental conations as an exogenous factors which played an important role in damaging of construction materials of the pyramid complex especially the main pyramid which constructed mainly by using poor construction materials physically and mechanically. The local bed /mother rock is susceptible for mechanical and chemical weathering for its weakness naturally and after reaction with the surrounding and environmental conditions such as winds, humidity and temperature leads to demolishing the structural materials of the pyramid then the partial/ full destruction for the pyramid.

Environmentally, Abusir climate is belonging to Giza governorate/area. It is well known that is nothing permanent so the climate changing from time to time through the history. Climate change represents important risks through the predicted sea level rise on the coastal zone that is already subsiding at approximately $3-5 \mathrm{~mm} /$ year at the Nile delta. The recent analyses of current climatic trends reveal a warming trend in recent decades with country averaged mean temperature increases of $1.4^{\circ} \mathrm{C}$ and $2.5^{\circ} \mathrm{C}$ projected by 2050 and 2100(Masria,A.2017) [18]. Egypt is part of the world and the climate change is notable last ten years and that plays a risky impact on archeological building materials. From the readings and recording for meteorological data in Giza noticed that the driest month is May with $0 \mathrm{~mm}$ of rain fall, the most precipitation falls in January. The warmest month of the year is July, with an average temperature of $27.5^{\circ} \mathrm{C}$, the difference in precipitation between the driest month and wettest month is $4 \mathrm{~mm}$ and during the year the average temperatures vary by $14.5^{\circ} \mathrm{C}$ Table 1,2 .

Egypt experiences dust storms in spring and early summer, with dry and dust-laden Khamasin wind usually arriving in April, but occasionally occurring in March and May. The winds form in low pressure areas in the Isthmus of Suez and sweep across the northern coast of Africa reaching high velocities and carrying great quantities of sand and dust from the deserts. These sandstorms, often accompanied by winds of up to 140 kilometers per hour, can cause temperatures to rise as much as $20^{\circ} \mathrm{C}$ in two hours and may blow continuously for three or four days at a time, then followed by an inflow of much cooler air(Ministry of Foreign Affairs of the Netherlands,2018) [19].

Table.1. Giza meteorological data for temperature by monthbetween January to December 2019, the variations of degrees are observed, from https://en.climate-data.org/africa/egypt/gizagovernorate/giza-551/\#climate-graph.

\begin{tabular}{|c|c|c|c|c|c|c|c|c|c|c|c|c|}
\hline & January & February & March & April & May & June & July & August & September & October & November & December \\
\hline $\begin{array}{l}\text { Avg. } \\
\text { Temperature } \\
\left({ }^{\circ} \mathrm{C}\right)\end{array}$ & 13 & 14 & 17.2 & 20.5 & 24 & 27.1 & 27.5 & 27.5 & 25.6 & 23.5 & 19.2 & 15 \\
\hline $\begin{array}{l}\text { Min. } \\
\text { Temperature } \\
\left({ }^{\circ} \mathrm{C}\right)\end{array}$ & 6.8 & 7.2 & 10.3 & 12.7 & 16.1 & 19.3 & 20.6 & 20.7 & 18.9 & 16.8 & 13 & 8.9 \\
\hline $\begin{array}{l}\text { Max. } \\
\text { Temperature } \\
\left({ }^{\circ} \mathrm{C}\right)\end{array}$ & 19.3 & 20.9 & 24.2 & 28.4 & 32 & 34.9 & 34.5 & 34.4 & 32.4 & 30.2 & 25.4 & 21.1 \\
\hline $\begin{array}{l}\text { Avg. } \\
\text { Temperature } \\
\left({ }^{\circ} \mathrm{F}\right)\end{array}$ & 55.4 & 57.2 & 63.0 & 68.9 & 75.2 & 80.8 & 81.5 & 81.5 & 78.1 & 74.3 & 66.6 & 59.0 \\
\hline $\begin{array}{l}\text { Min. } \\
\text { Temperature } \\
\left({ }^{\circ} \mathrm{F}\right)\end{array}$ & 44.2 & 45.0 & 50.5 & 54.9 & 61.0 & 66.7 & 69.1 & 69.3 & 66.0 & 62.2 & 55.4 & 48.0 \\
\hline $\begin{array}{l}\text { Max. } \\
\text { Temperature } \\
\left({ }^{\circ} \mathrm{F}\right)\end{array}$ & 66.7 & 69.6 & 75.6 & 83.1 & 89.6 & 94.8 & 94.1 & 93.9 & 90.3 & 86.4 & 77.7 & 70.0 \\
\hline $\begin{array}{l}\text { Precipitation } \\
\text { / Rainfall } \\
\text { (mm) }\end{array}$ & 4 & 3 & 2 & 1 & 0 & 0 & 0 & 0 & 0 & 0 & 3 & 4 \\
\hline
\end{tabular}

Table.2. Giza meteorological data between 4 June to 29 May 2019 for wind speed, humidity and 
wind speed as shown in red bold numbers in the table, from https://en.climate- 180 data.org/africa/egypt/giza-governorate/giza-551/\#climate-graph.

\begin{tabular}{|c|c|c|c|c|c|c|c|}
\hline 2 Date & Weather & Max. & Min. & Rainrisk & Windspeed & $\begin{array}{l}\text { Precipitation / } \\
\text { Rainfall (mm) }\end{array}$ & Humidity \\
\hline 29. May & $\begin{array}{c}\text { Few } \\
\text { clouds }\end{array}$ & $\begin{array}{l}28^{\circ} \mathrm{C} \\
83^{\circ} \mathrm{F}\end{array}$ & $\begin{array}{l}18^{\circ} \mathrm{C} \\
64^{\circ} \mathrm{F}\end{array}$ & $0 \%$ & $10 \mathrm{~km} / \mathrm{h}$ & $0 \mathrm{~mm}$ & $48 \%$ \\
\hline 30. May & Clear sky & $\begin{array}{l}29^{\circ} \mathrm{C} \\
84^{\circ} \mathrm{F}\end{array}$ & $\begin{array}{l}17^{\circ} \mathrm{C} \\
63^{\circ} \mathrm{F}\end{array}$ & $0 \%$ & $10 \mathrm{~km} / \mathrm{h}$ & $0 \mathrm{~mm}$ & $47 \%$ \\
\hline 31. May & Clear sky & $\begin{array}{l}31^{\circ} \mathrm{C} \\
88^{\circ} \mathrm{F}\end{array}$ & $\begin{array}{l}18^{\circ} \mathrm{C} \\
64^{\circ} \mathrm{F}\end{array}$ & $0 \%$ & $10 \mathrm{~km} / \mathrm{h}$ & $0 \mathrm{~mm}$ & $43 \%$ \\
\hline 1. June & Clear sky & $\begin{array}{l}38^{\circ} \mathrm{C} \\
100^{\circ} \mathrm{F}\end{array}$ & $\begin{array}{l}21^{\circ} \mathrm{C} \\
71^{\circ} \mathrm{F}\end{array}$ & $0 \%$ & $14 \mathrm{~km} / \mathrm{h}$ & $0 \mathrm{~mm}$ & $21 \%$ \\
\hline 2. June & $\begin{array}{l}\text { Few } \\
\text { clouds }\end{array}$ & $\begin{array}{l}41^{\circ} \mathrm{C} \\
106^{\circ} \mathrm{F}\end{array}$ & $\begin{array}{l}21^{\circ} \mathrm{C} \\
70^{\circ} \mathrm{F}\end{array}$ & $0 \%$ & $18 \mathrm{~km} / \mathrm{h}$ & $0 \mathrm{~mm}$ & $19 \%$ \\
\hline 3. June & $\begin{array}{l}\text { Few } \\
\text { clouds }\end{array}$ & $\begin{array}{l}35^{\circ} \mathrm{C} \\
96^{\circ} \mathrm{F}\end{array}$ & $\begin{array}{l}20^{\circ} \mathrm{C} \\
68^{\circ} \mathrm{F}\end{array}$ & $0 \%$ & $18 \mathrm{~km} / \mathrm{h}$ & $0 \mathrm{~mm}$ & $43 \%$ \\
\hline 4. June & Clear sky & $\begin{array}{l}36^{\circ} \mathrm{C} \\
96^{\circ} \mathrm{F}\end{array}$ & $\begin{array}{l}21^{\circ} \mathrm{C} \\
70^{\circ} \mathrm{F}\end{array}$ & $0 \%$ & $17 \mathrm{~km} / \mathrm{h}$ & $0 \mathrm{~mm}$ & $32 \%$ \\
\hline
\end{tabular}

From previous meteorological data and statistics the pyramid construction materials from sandy limestone as core stone which came from local formation/ quarry of Abusir and white limestone as casing stone brought from Tura and Massara quarry are subjected to environmental conditions such as humidity, temperature and wind waves which resulted in many shapes of decay for the construction materials for the pyramid of Sahure, the shapes of decayed stones as following:

\subsection{Delamination}

The two kinds of limestone (sedimentary rocks) have been subjected to delamination process because of lamination of limestone originally. The detachment of construction materials of the pyramid backs to exposition to thermal cycling, variations of temperature, either increases or decreases, will result respectively in volume expansion or contraction/shrinkage so the repeated heating and cooling of the stones will finally lead to detachments (siegesmund, $S$ and Snethlage,R.2011) [20]. In fact there are different sub-sorts of the delamination such as (Comitéscientifique international "Pierre" de l'ICOMOS, 2016) [21]:

1) Exfoliation; it is thin layers like book pages and slightly bonded figure 7.

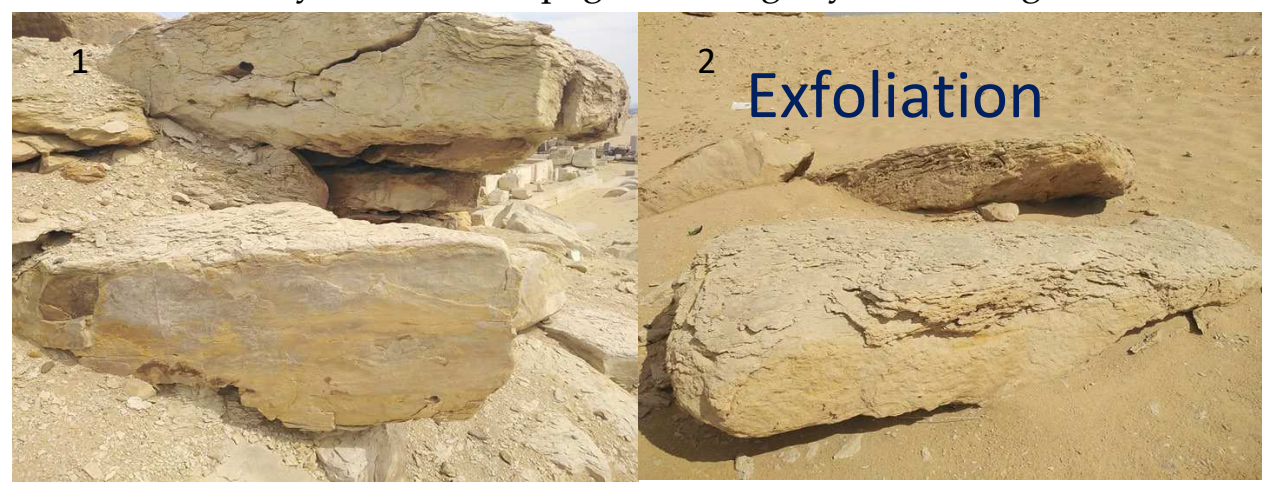

Figure.7.1,2 Exfoliated stones of the pyramid built materials.

2) Scaling; it is sort of delamination and totally of stone body, figure 8 . 


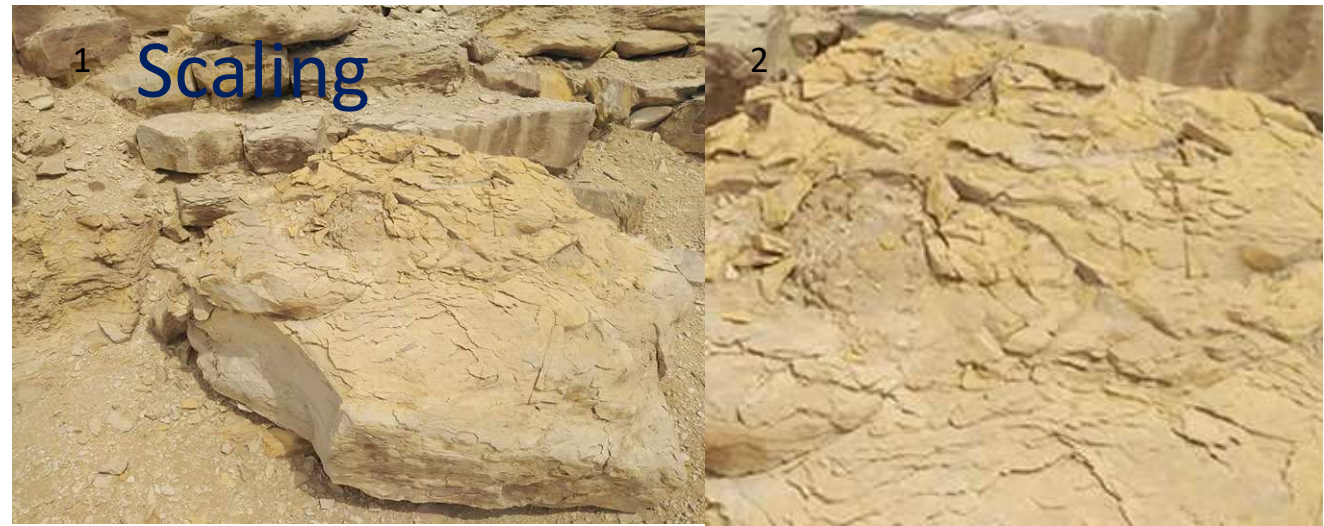

Figure.8.1,2 scaled limestone blocks of pyramid construction.

3) Powdering or Chalking; it is the disintegration of the stone grains to power shape, figure 9.

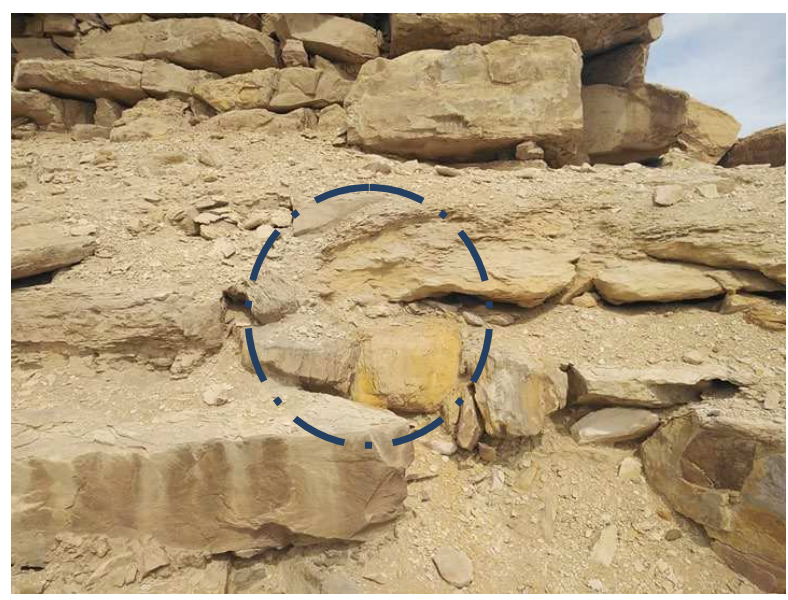

Figure.9. Powdered sandy limestone of pyramid core blocks.

4) ALveolization or Honeycomb; it is kind of cavities created in most construction materials surfaces of the pyramid and it looks like the air sacs in the lung, it is described as an extensive network of small cavities that from honeycomb patterns, the sickness of 


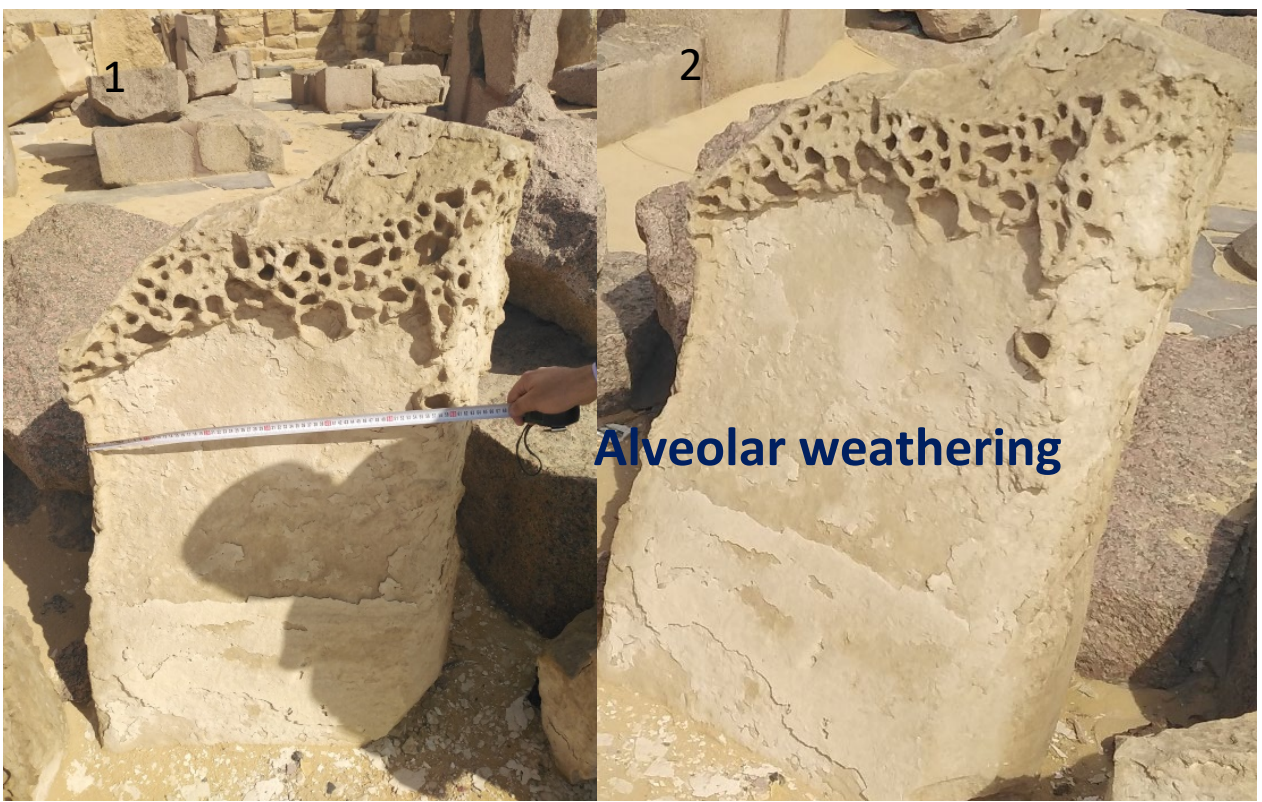

Figure.10. 1,2 Alveolization in the pyramid construction materials.

According to the geological setting of Abusir archaeological site and the recordings of historical seismogical data, the pyramid structure have suffered from shear forces due to previous earthquakes and stresses due to soil settlements, the most important factor that effectively caused major deterioration and structural problems of the red pyramid near to Abusir archaeological site was the old earthquakes. specifically the last Dahshur earthquake happened in 1992 AD, which estimated with a local magnitude $5.3 \mathrm{M}$ (duration magnitude) on the Richter scale occurred at Dahshur (Hemeda,S et al 2019) $[23,24]$. So the crumbling and structural cracks in the pyramid of Sahure occurred as a result of earthquakes hits in addition to the environmental conditions/ weathering impacts figure 11 and 12. 

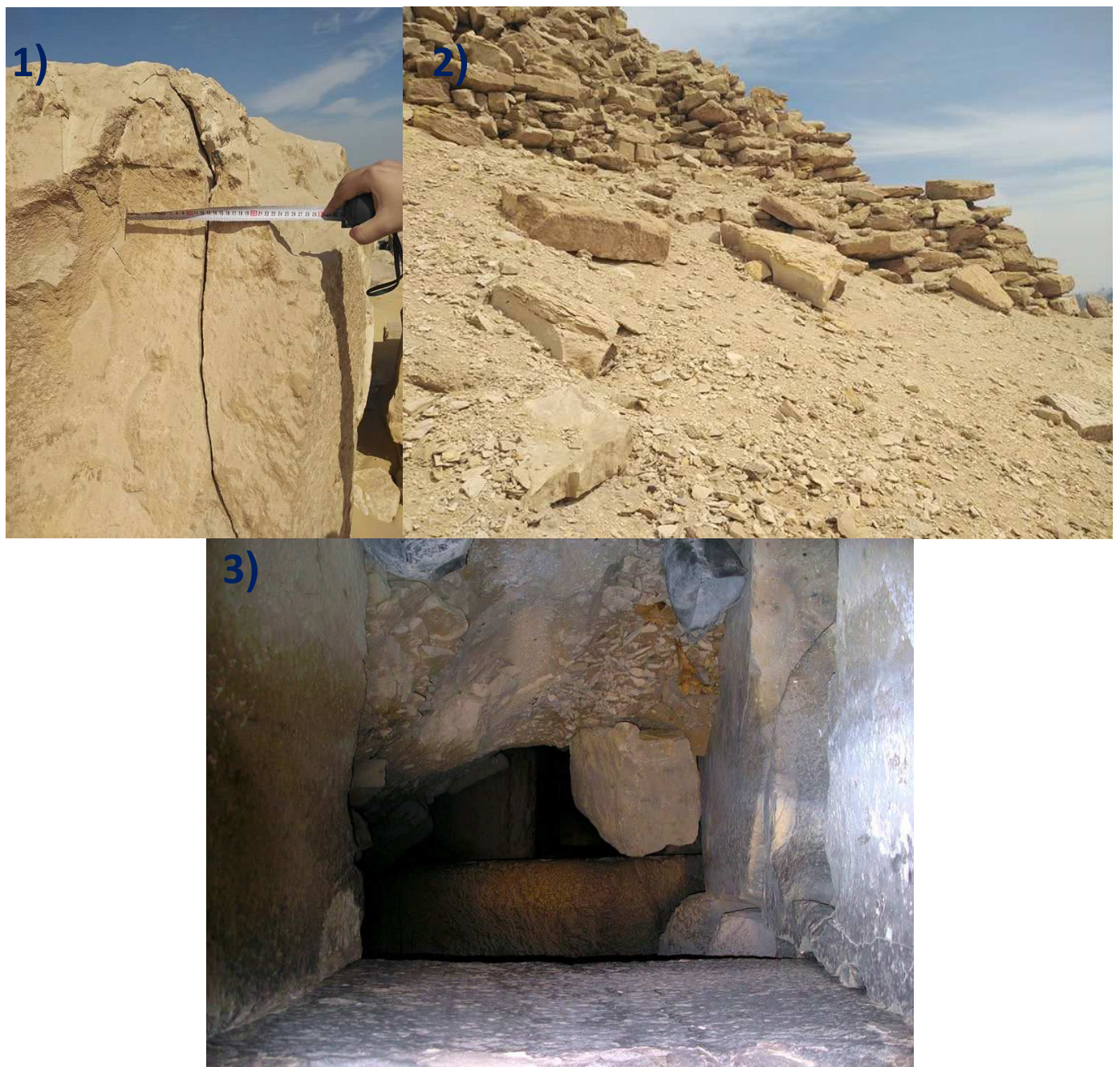

Figure.11. The blocks splitting, cracking and crumbling of the Sahure pyramid, 3) from, https://ancientegyptianfacts.com/abusir.html/entrance-sahure.

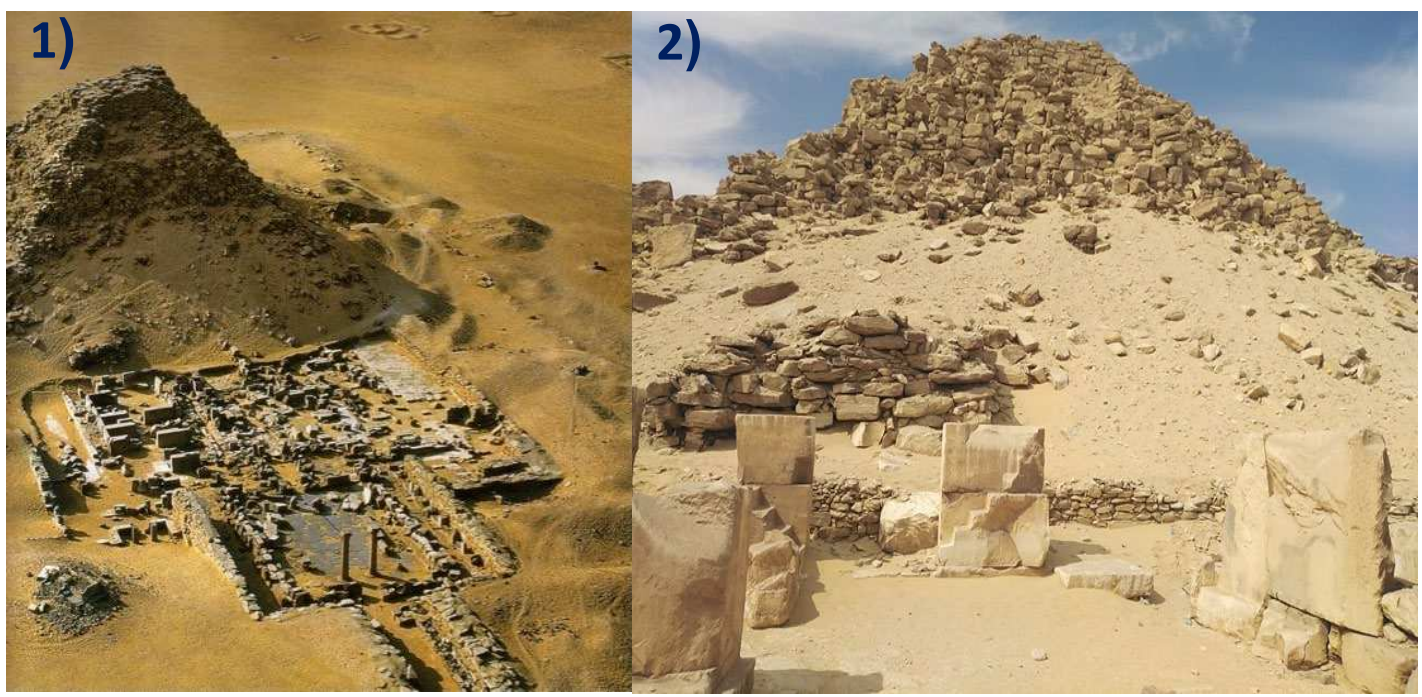

Figure.12. 1,2 1) Aerial view for the pyramid of Sahure and the state of preservation, 
Some fragments from the quarries which are represented for the construction materials and aged naturally in same conditions had been collected for analysis and investigation figure 13. Some in situ visits and woks made to record all problems of the pyramid, structural deficiencies, documentation, and geo-environmental analysis. Many laboratory tools and materials had been utilized to analyze, investigate and to carry out the physical properties for evaluation the continuity and cohesiveness of the pyramid construction materials against environmental conditions and identifying. For examination and investigation, visual examinations, digital microscope, polarizing microscope (rocks microscope) had been carried out to examine and investigate the casing limestone and the pyramid core stone (inner part) which made of sandy limestone. For the analysis, X-Ray fluorescence (XRF) on an advanced Wavelength Dispersive Spectrometer Axios, WD-XRF Spectrometer and X-Ray diffraction (XRD) had been used through $\mathrm{Cu} \mathrm{K}$ radiation. The filtering speed is $2 \mathrm{~h}=1$ degree/min at steady voltage $40 \mathrm{kV}$, and $30 \mathrm{~m}$ and utilizing PW $1480 \mathrm{X}$-beam diffraction for identification for the construction materials of the Sahure pyramid. For physical properties, eighteen cubes had been prepared and tested physically for the two kinds of pyramid construction where the one is from local quarry of Abusir (Laminated sandy argillaceous limestone (marl) and the other kind of stone from Tura and Massara quarries. The objectives of carrying out physical characteristics are 1) to identify the physical behavior of stones with environmental conditions,2)to evaluate the durability state of stones blocks of the Sahure pyramid. Some fragments from the quarries which are represented for the construction materials and aged naturally in same conditions had been collected for analysis and investigation. Some in situ visits and woks made to record the all problems of the pyramid, structural deficiencies, documentation, and geo-environmental analysis.

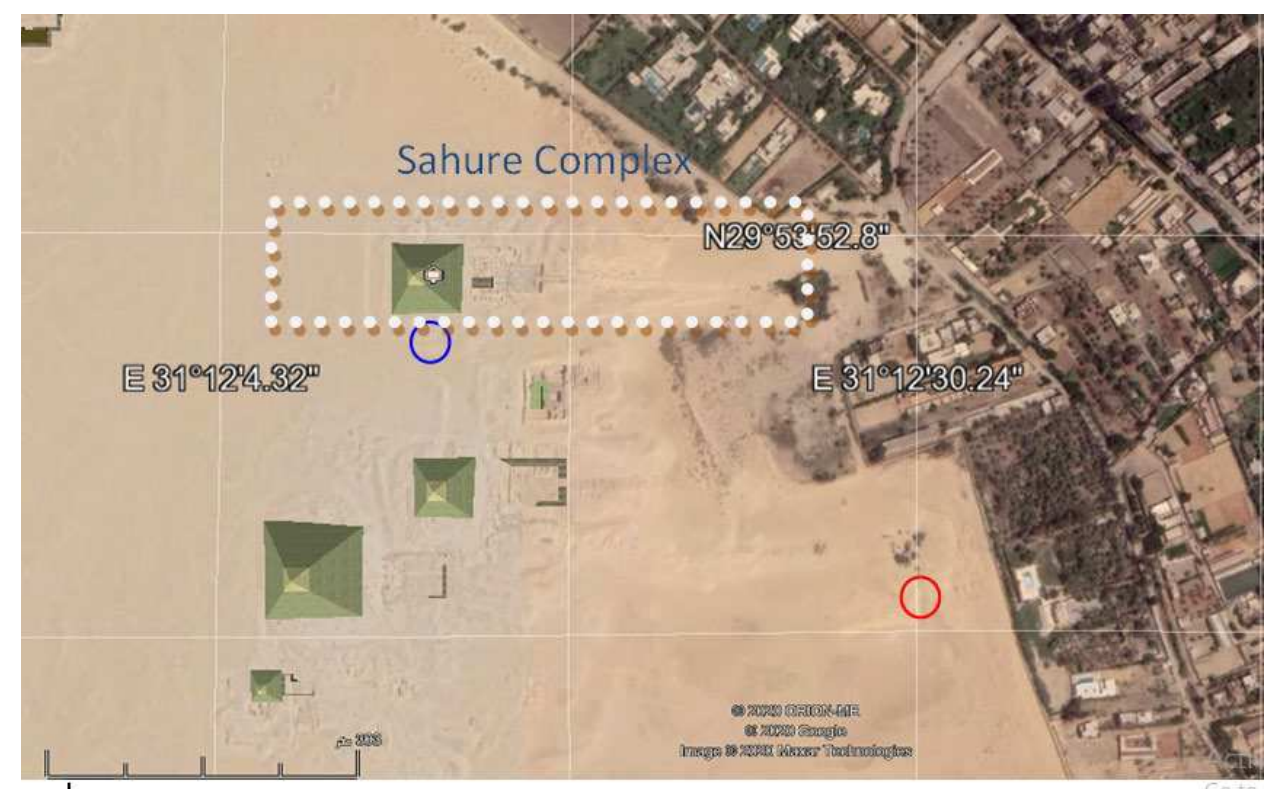

Figure.13. Google earth map shows the sampling areas which representative for the construction material of the pyramid, red circle: local quarry represents the inner stones which used for construction materials of the pyramid, Blue circle: fallen and highly weathered fragments/samples represent the core, casing and mortar samples used as construction materials for the pyramid.

\section{5-1 Visual and morphological examination}

Visual examination had been carried out to collect much data and take some accurate photos for the construction materials to identify and highlight the specific problems of the pyramids and kind of construction materials of the pyramid. Morphological examination had been carried out by using digital microscope (USB digital microscope with tripod. Magnification: 20-400x.digital camera: $1.3 \mathrm{Mpx}$ ) with a significant magnification to identify the morphology of stone samples. Moreover, polarized light microscope (PLM) has 
been carried out in central lap of Egyptian general authority of mineral resources as a geo-mineralogical analysis for stone samples. It was used to identify the minerals of stones of the pyramid and to specify the alteration processes of the stones as result of the geo-environmental effects for the building materials of the pyramid.

5-2 Mineralogical characterization

X-Ray diffraction (XRD) on an advanced Wavelength Dispersive Spectrometer Axios, WD-XRF Spectrometer and X-Ray diffraction (XRD) had been used through $\mathrm{Cu} \mathrm{K}$ radiation had been used to

Mineralogical characterizations for the pyramid building materials have been operated by utilizing X-Ray

For determination of petro-physical properties, nine cubic stone samples had been prepared form gravity, apparent density and porosity. The petro-physical properties reflect well the physical behavior of the natural stone and assess the durability of pyramid construction materials.

\section{Petro-graphical, investigative and analytical pathology for the construction materials of the} pyramid

The construction materials of Sahure pyramid are mainly composed of core weak stone (Laminated sandy argillaceous limestone (marl) as shown in table 3 the results of XRD analysis which brought from the local quarry of Abusir area, casing stone (Fossiliferous Limestone (biomicrite) as shown in table 5 and joint basaltic mortar as shown in table 9the results of XRD analysis (some researchers said that they used mud mortars as local material for blocks joining) the basaltic mortar is a unique building material had been discovered by the author and it could be the 


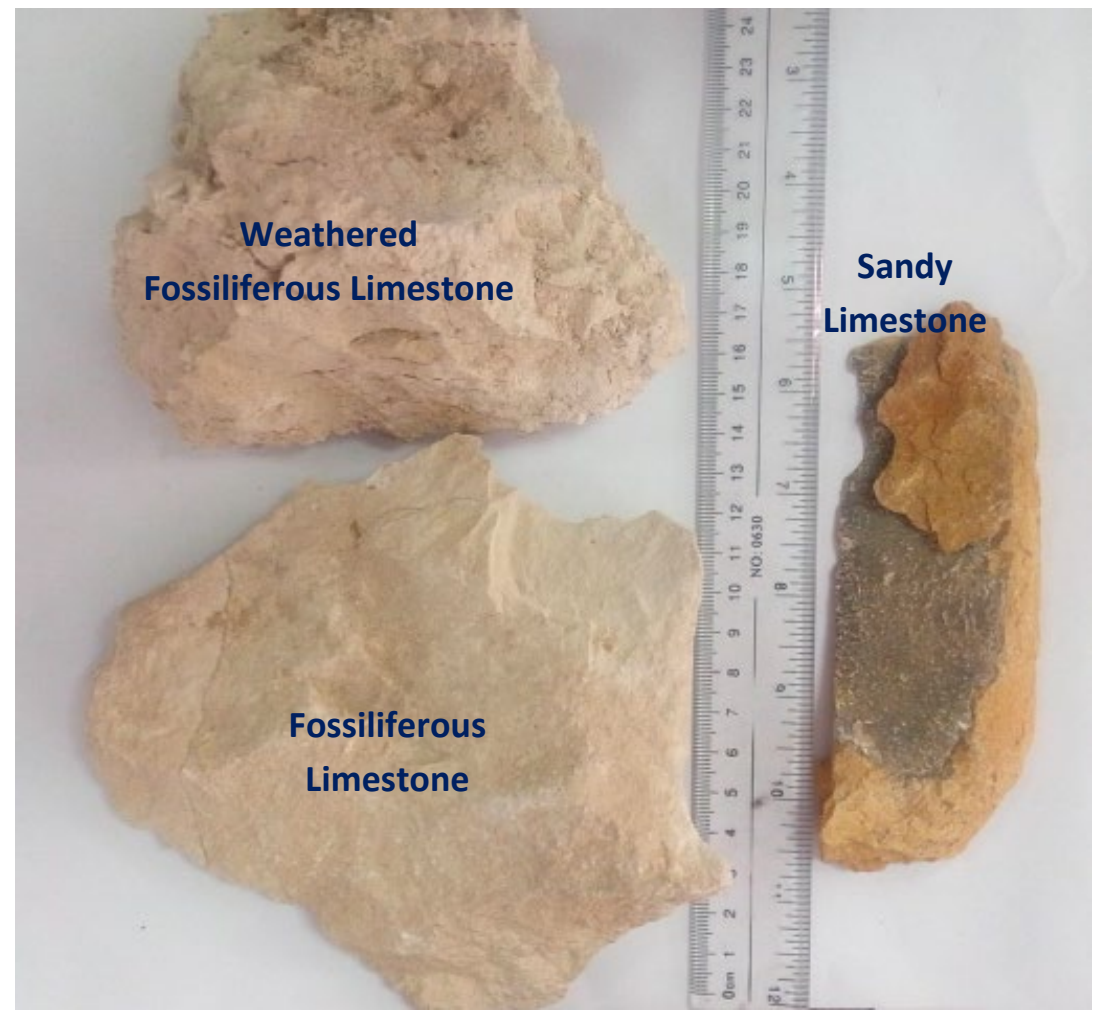

Figure.14. The construction materials of Sahure pyramid, Fossiliferous Limestone as a casing stone and Sandy limestone as a core building material.

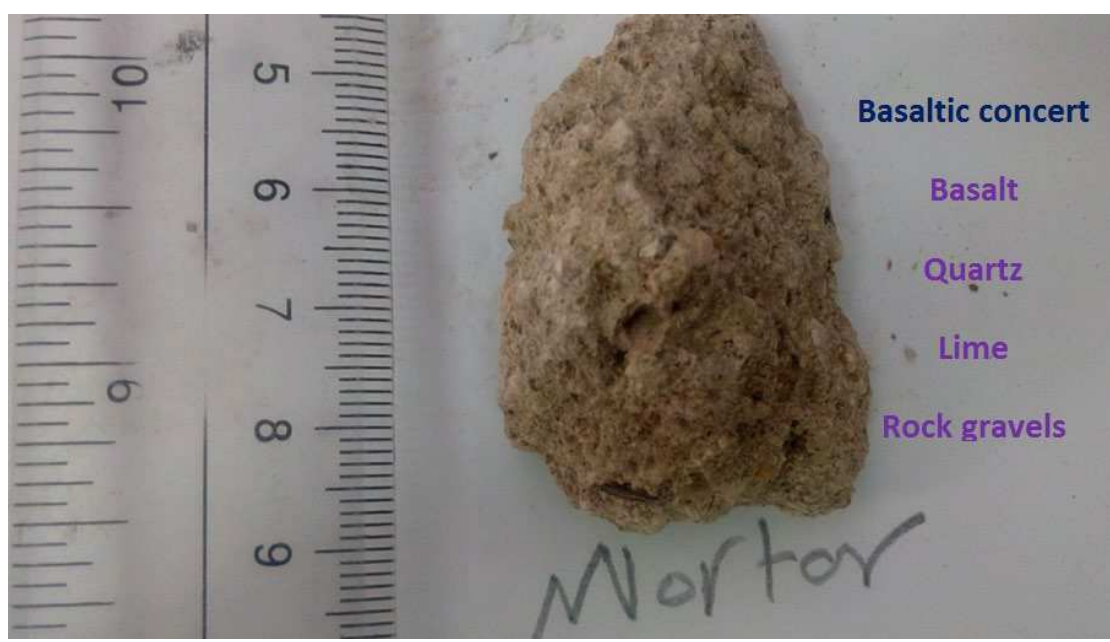

Figure.15. Archeological basaltic concert (basaltic mortar) as a building material in Sahure pyramid complex.

From visual, microscopic and field inspection the construction building materials are in hazardous state and they are subjected to accumulative chemical and mechanical weathering, originally the quality of the local quarry is so poor as the clay minerals occur as very finegrained $<1 / 256 \mathrm{~mm}$ [25] anhedral aggregates admixed with carbonates and Iron oxides are present in minor amount and occur as very fine-grained aggregates admixed with carbonates and clay minerals and disseminated in the rock, as a result of that the stones of core building materials are high porous building materials and inhomogeneous and that reflect weak resistance to environmental and weathering impacts and show low durability. The core stone of Sahure 
pyramid is Laminated sandy argillaceous limestone marl (organic sedimentary rock). The stone is thinly laminated due to relative variation in mineral compositions, fissile, exhibiting obvious lamination. Microscopically, the core stone texture of the pyramids very fine to fine-grained. Significant amount of microfossils and fossil fragments are observed scattered in the matrix. Considerable amount of sand grains are observed scattered in the sample. Some irregular pore spaces and channels are detected in the stone as shown figure 16 under USB digital microscope.

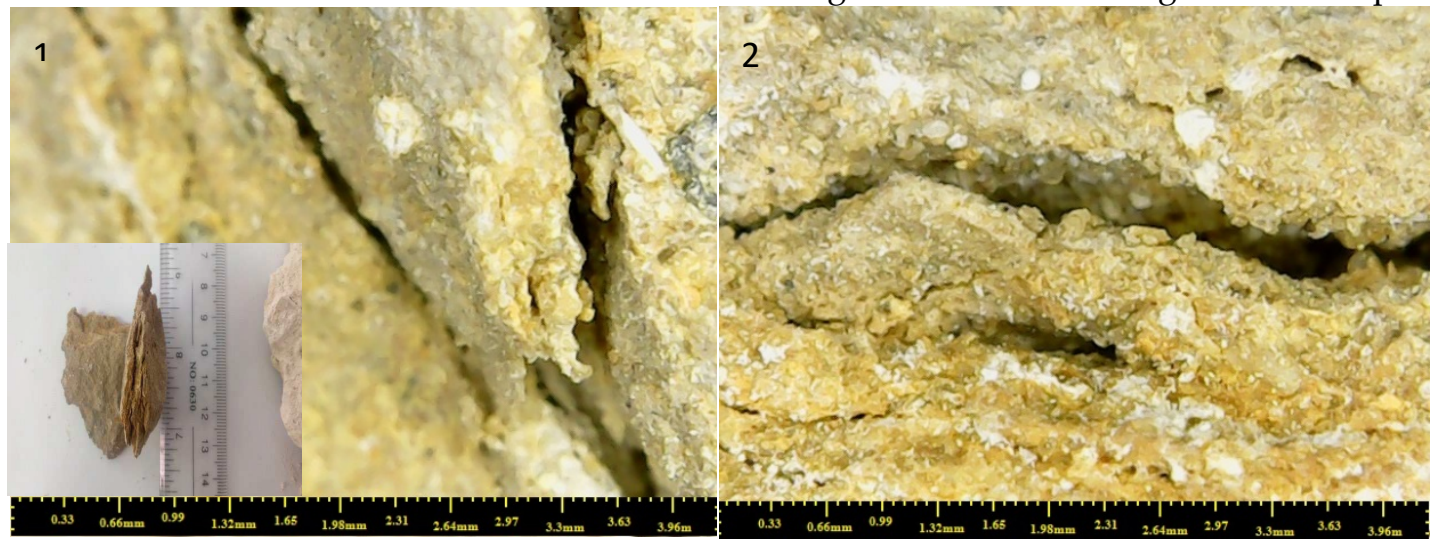

Figure.16.1,2 photographs under digital microscope shows the grains of the quartz admixed with calcite, the channels and micro cracks are detected.

Petro-graphically, the core stone investigated under polarizing microscope(3. 25X, C.N ) in the very fine to fine-grained, composed essentially of carbonates (calcite and dolomite), clay minerals and quartz associated with minor amounts of iron oxides and opaque minerals and rare amounts of feldspar, glauconite and phosphate mineral (collophane). Carbonates occur as very fine-grained, anhedral to subhedral crystals that represent the matrix of the rock. Clay minerals occur as very fine-grained anhedral aggregates admixed with carbonates. Quartz is present as very fine to fine grains crystals scattered in the matrix. Iron oxides are present in minor amount and occur as very fine-grained aggregates admixed with carbonates and clay minerals and disseminated in the rock. Significant amount of microfossils and fossil fragments are observed scattered in the matrix. Some irregular pore spaces and channels are detected in the sample; some microfossils are filled by recrystallized secondary calcite and secondary quartz. Some microvienlets filled by recrystallized secondary calcite, quartz and iron oxides cut across the rock. Quartz presents as a secondary replacement mineral over carbonates. Ankerite may present as alternation mineral after calcite (dolomatization process) figure17. 


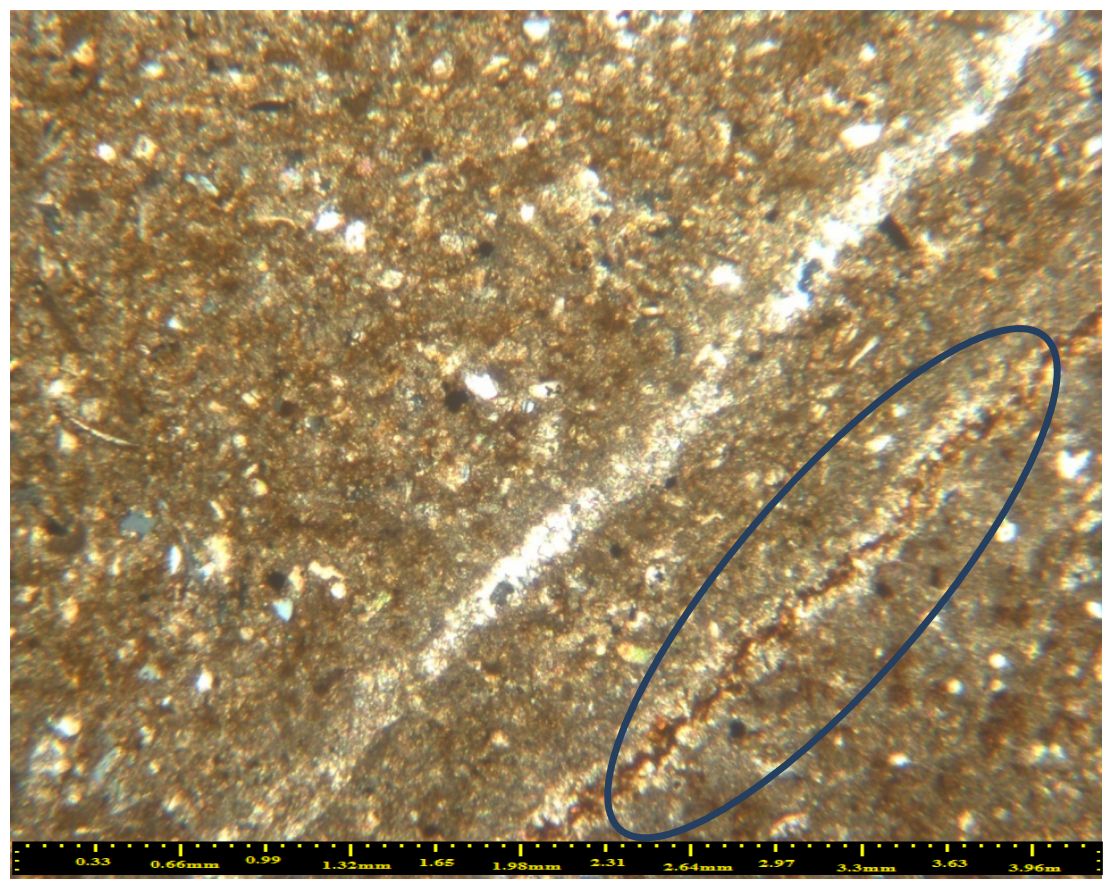

Figure.17. Thin section for the core stone investigated under polarizing microscope (3. 25X, C.N),

X-Ray diffraction had been carried on for the core stone sample for identification for the constituents of the stone where the components of core stone are calcite, ankerite and quartz figure 18, ankeriteis an iron carbonate mineral(Marini, L.2007)[26], it is occurs with siderite in metamorphosed ironstones and sedimentary babded iron formations. It is also occurs in carobonatites. In sediments it occurs as authigenic, digenetic minerals and as a product of hydrothermal deposition(Marini, L.2007) [26].Ankerite may present as alternation mineral after calcite (dolomatization process).quartz associated with minor amounts of iron oxides and opaque minerals and rare amounts of feldspar, glauconite and phosphate mineral (collophane).

Table.3. XRD analysis results for the core stone of Sahure pyramid. .

\begin{tabular}{|c|c|c|c|}
\hline Ref. Code & Mineral Name & Chemical Formula & Semi Quant [\%] \\
\hline $1-089-1304$ & Calcite, magnesium & ( Mg0.03 Ca0.97 ) ( C O3 ) & 79 \\
\hline 10-041-0586 & Ankerite & $\mathrm{Ca}(\mathrm{Fe}+2, \mathrm{Mg})(\mathrm{C} \mathrm{O} 3) 2$ & 18 \\
\hline $1-085-0865$ & Quartz & Si 02 & 3 \\
\hline
\end{tabular}

Table.4. Major elements fourth core stone of Sahure by using XRF.

\begin{tabular}{cccccccccccccc}
\hline D.N & $\mathrm{SiO} 2$ & $\mathrm{TiO} 2$ & $\mathrm{Al} 2 \mathrm{O} 3$ & $\mathrm{Fe} 2 \mathrm{O} 3$ & $\mathrm{MnO}$ & $\mathrm{MgO}$ & $\mathrm{CaO}$ & $\mathrm{Na} 2 \mathrm{O}$ & $\mathrm{K} 2 \mathrm{O}$ & $\mathrm{P} 2 \mathrm{O} 5$ & $\mathrm{Cl}$ & $\mathrm{So3}$ & $\mathrm{Lol}$ \\
\hline 1 & 4.80 & 0.10 & 0.40 & 5.10 & 0.09 & 2.40 & 47.90 & 0.09 & 0.06 & 0.02 & 0.23 & 0.69 & 37.90 \\
\hline
\end{tabular}




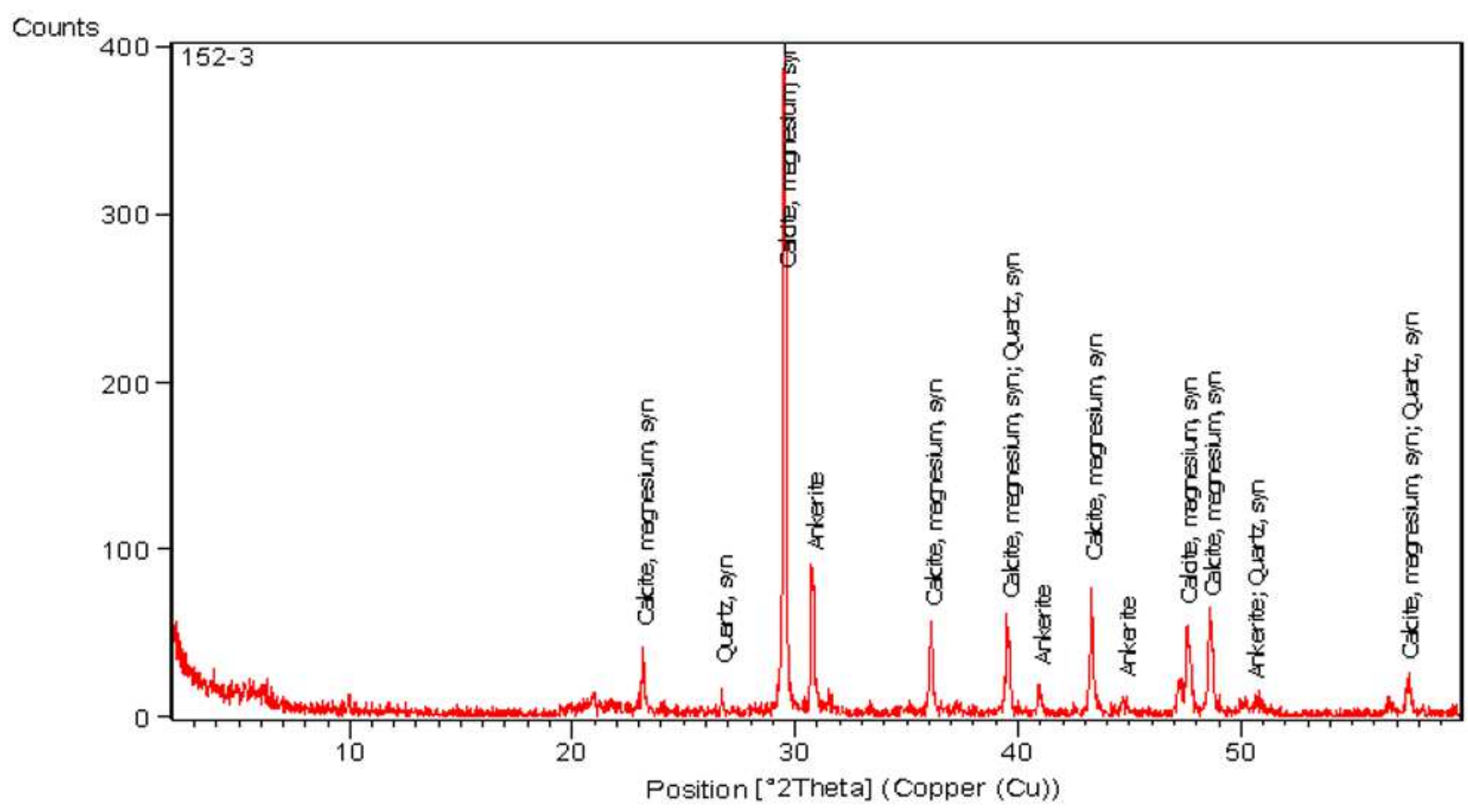

Figure.18. XRD pattern for the core stone of Sahure pyramid.

The casing stone of the pyramid had been brought from the Tura and Massara quarries on the other hand of western bank of Nile. This kind of stone (Fossiliferous Limestone (biomicrite)) is a very white and more resistant for the environmental conditions after it was polished and prepared to blocks for the construction of the pyramids but generally the chemical limestone is harder and homogeneous than fossiliferous limestone. Accumulative impact of weathering can affect the casing stone but not more the core stone especially most of core blocks converted to powered shape unlikely the casing stone is still durable and resistant; samples have been prepared and examined under digital microscope to find that the stone is a very fine-grained (micrite). Significant amount of microfossils and fossil fragments are observed scattered in the matrix. Some irregular pore spaces are detected in the sample. Microvienlets filled by recrystallized calcite and secondary quartz are observed. Comb texture is observed in some microvienlets figure19. In weather samples of casing stones, the sample is very fine to fine-grained. Significant amounts of microfossils of different sizes and shapes are scattered in the very fine-grained matrix of calcite. Some irregular pore spaces are present in the carbonate matrix of the stone and Comb texture is observed figure 20.

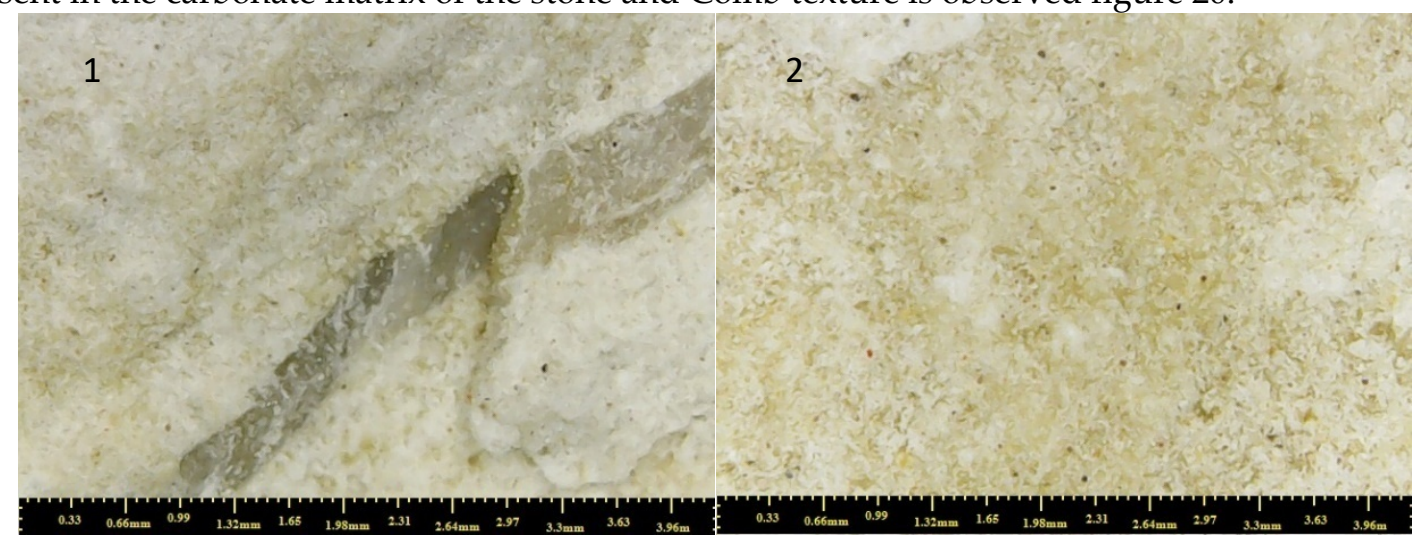

Figure.19. 1,2 Microscopic photos for the unweathered casing limestone of the pyramid. 


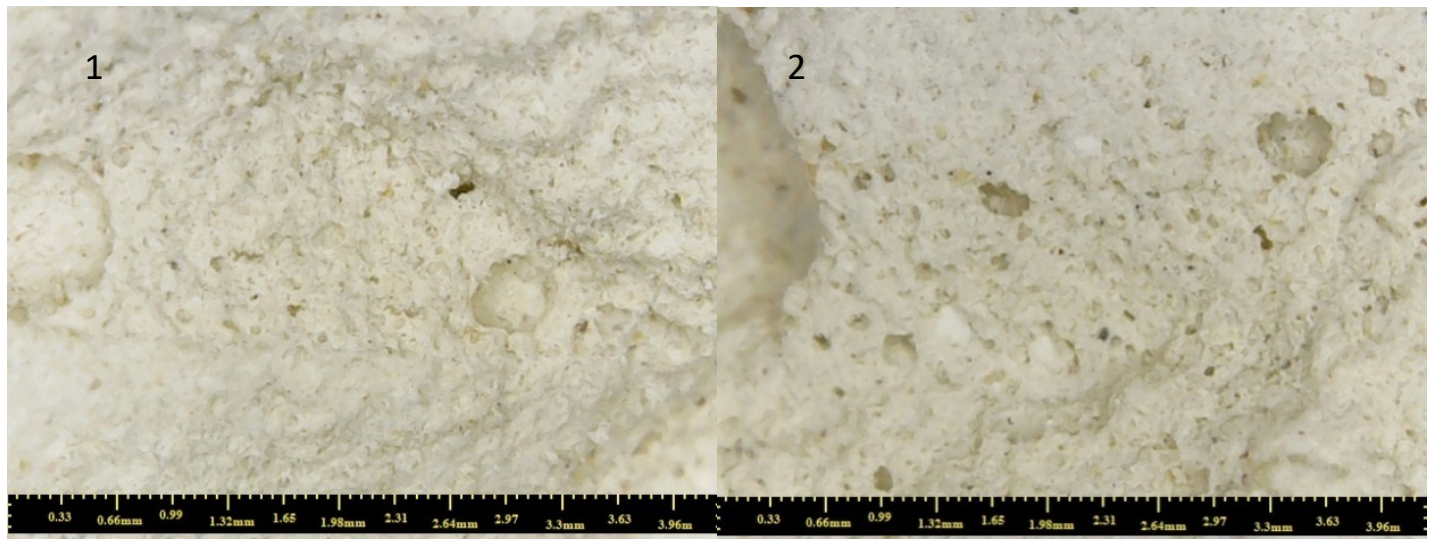

Figure.20. 1.2 Microscopic photos for the weathered casing limestone of the pyramid, some irregular

Additionally, the casing stone is investigated by using polarizing microscope(3. 25X, C.N ), for the un weathered sample, the rock is composed mainly of very fine-grained calcite (micrite) as the essential component associated with minor amounts of ankerite (ferrodolomite) and rare iron oxides, quartz, phosphate mineral (collophane) and opaques. Calcite represents the matrix of the rock and occurs as very fine-grained (micrite), anhedral to subhedral interlocked crystals. Iron oxides are observed as staining over some parts of the sample. Quartz is detected as very finegrained crystals scattered in the matrix. Phosphate occurs as very fine bone fragments scattered in the rock. Considerable amount of microfossils and fossil fragments are observed scattered in the matrix. The microfossils are filled by recrystallized fine-grained calcite. Some pores of irregular shapes and various sizes are observed scattered in the rock. Microvienlets filled by recrystallized calcite and secondary quartz are observed cutting through the sample. Some microfossils are filled by recrystallized secondary calcite (sparite). The rock is cut by interstitial microvienlets filled by recrystallized secondary calcite and traces of secondary quartz. Quartz presents as a secondary replacement mineral over carbonates, especially microfossils figure 21.

For the weathered samples, the stone is composed mainly of calcite and quartz as the essential components associated with minor amount of ankerite (ferrodolomite) and rare amounts of feldspars, gypsum, biotite, cellophane, opaque minerals, iron oxides and clay minerals. Calcite occurs as very fine-grained (micrite), anhedral crystals that represent the matrix of the sample. Quartz occurs as very fine to fine-grained, anhedral grains scattered in the matrix. Significant amounts of microfossils of different sizes and shapes are scattered in the matrix of the sample. Some microfossils are filled by recrystallized secondary calcite (sparite). Some parts of the rock are stained by traces of iron oxides. Microfossils are filled by recrystallized secondary calcite. Secondary quartz replaces calcite both in the matrix and in some microfossils. Secondary gypsum replaces calcite and partially fills cavities and pore spaces figure 22. 


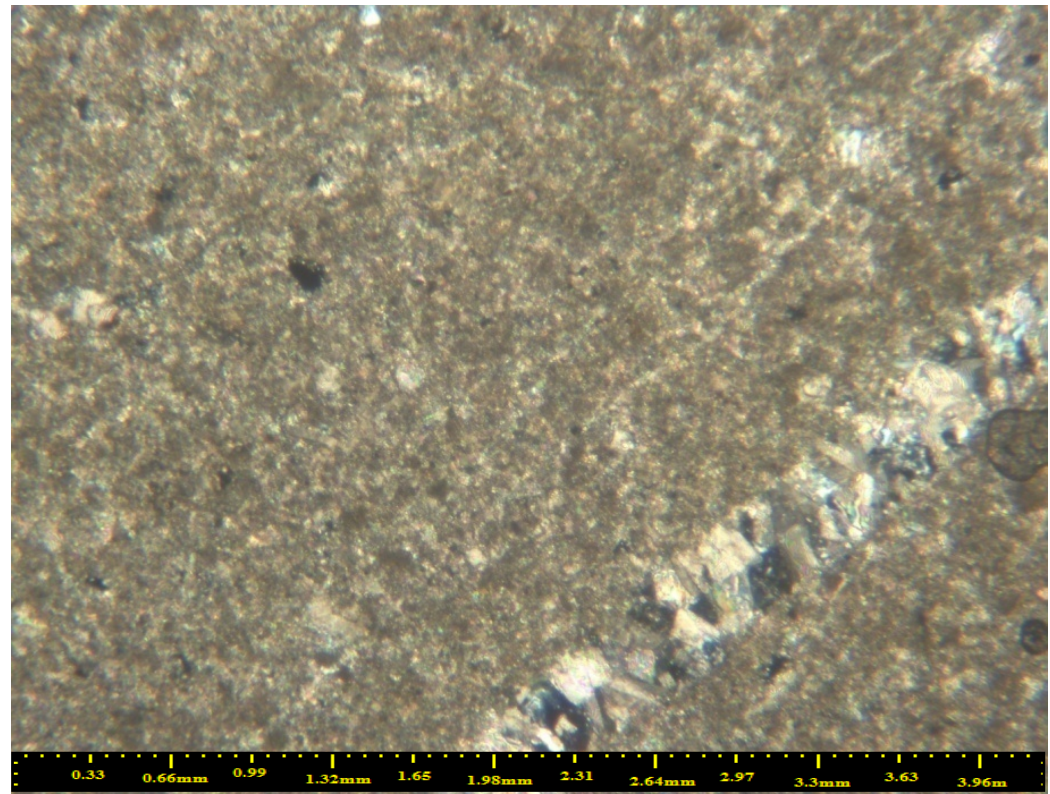

Figure.21. The casing stone under polarizing microscope (2. 25X, C.N), the stone is cut by interstitial microvienlets filled by recrystallized secondary calcite and traces of secondary quartz. Quartz presents as a secondary replacement mineral over carbonates, especially microfossils.

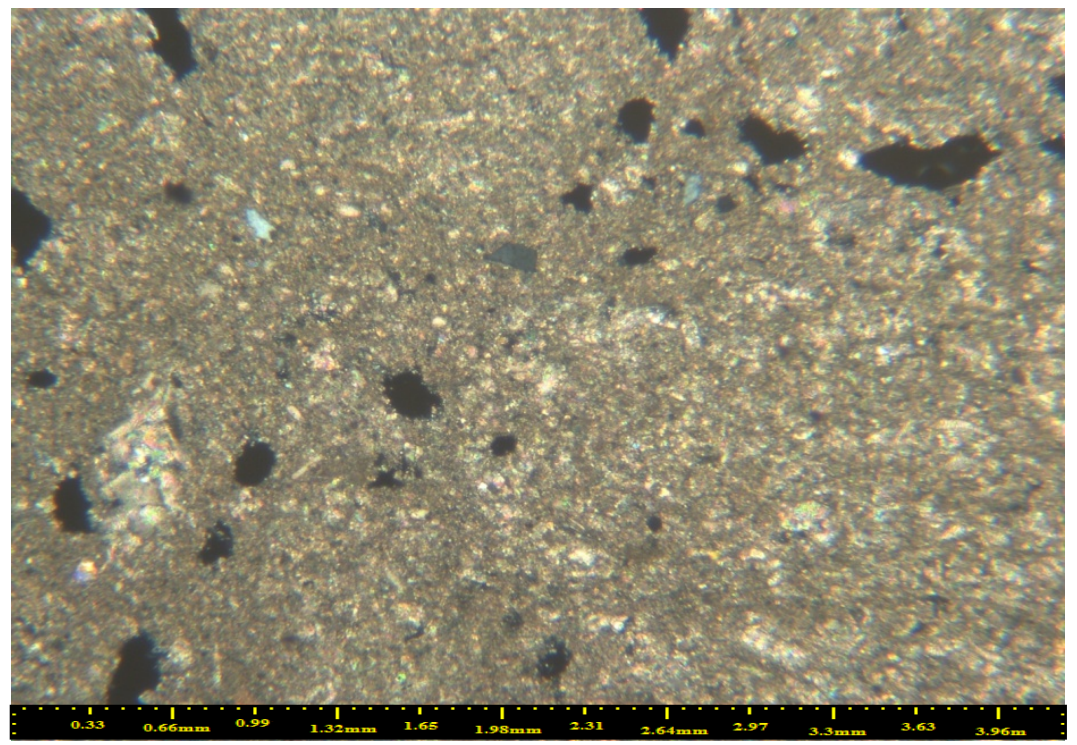

Figure.22. The casing stone under polarizing microscope (1. 63X,C.N),Secondary quartz replaces calcite both in the matrix and in some microfossils. Secondary gypsum replaces calcite and partially

Covering stone of the pyramid have been identified by using XRD and XRF, two kinds of stone 
Table.5. XRD results for the constituents of the unweathered casing limestone of the pyramid.

\begin{tabular}{|c|c|c|c|}
\hline Ref. Code & Mineral Name & Chemical Formula & Semi Quant [\%] \\
\hline 01-076-2713 & Calcite & $\mathrm{Ca}(\mathrm{C} \mathrm{O3}$ ) & 93 \\
\hline 00-041-0586 & Ankerite & $\mathrm{Ca}(\mathrm{Fe}+2, \mathrm{Mg})(\mathrm{C} \mathrm{O} 3) 2$ & 7 \\
\hline
\end{tabular}

Table 6. XRF results show he major elements of the unweathered casing limestone of the pyramid.

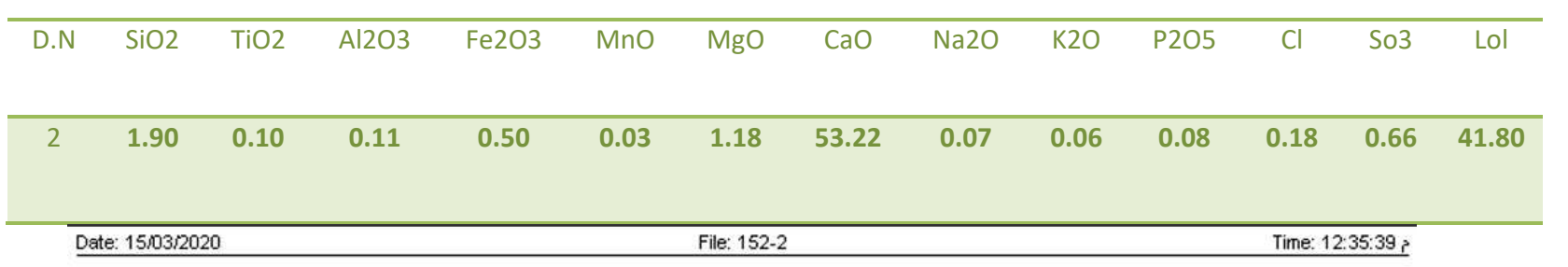

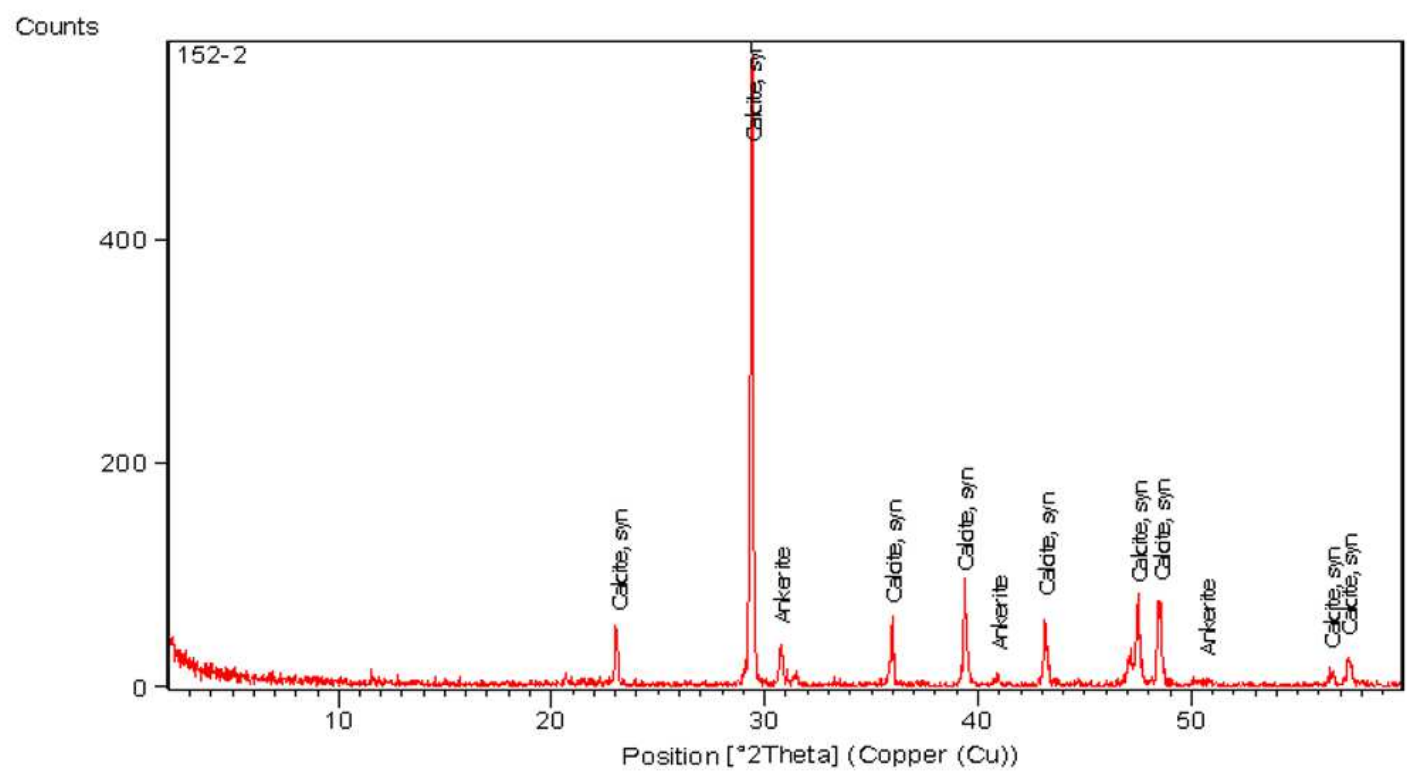

Figure.23. XRD pattern of the unweathered casing limestone of the pyramid.

Table.7. XRD results for the constituents of the weathered casing limestone of the pyramid.

\section{Ref. Code \\ Mineral Name \\ Chemical Formula \\ Semi Quant [\%]}

\begin{tabular}{|c|c|c|c|}
\hline $01-086-2335$ & Calcite, magnesium & ( Mg.064 Ca.936) ( C O3 ) & 80 \\
\hline $01-085-0865$ & Quartz & Si O2 & 15 \\
\hline $00-006-0046$ & Gypsum & Ca S O4 -2 H2 O & 2 \\
\hline $00-012-0088$ & Ankerite & Ca ( Mg0.67 Fe0.33 +2 ) ( C O3 )2 & 3 \\
\hline
\end{tabular}


Table 8. XRF results show he major elements of the weathered casing limestone of the pyramid.

\begin{tabular}{ccccccccccccccc}
\hline D.N & SiO2 & TiO2 & Al2O3 & Fe2O3 & MnO & MgO & $\mathrm{CaO}$ & $\mathrm{Na} 2 \mathrm{O}$ & $\mathrm{K} 2 \mathrm{O}$ & $\mathrm{P} 2 \mathrm{O} 5$ & $\mathrm{Cl}$ & $\mathrm{So3}$ & Lol \\
\hline 3 & 3.54 & 0.12 & 0.18 & 0.52 & 0.01 & 1.10 & 52.74 & 0.04 & 0.01 & 0.01 & 0.19 & 0.69 & 40.50 \\
\hline
\end{tabular}

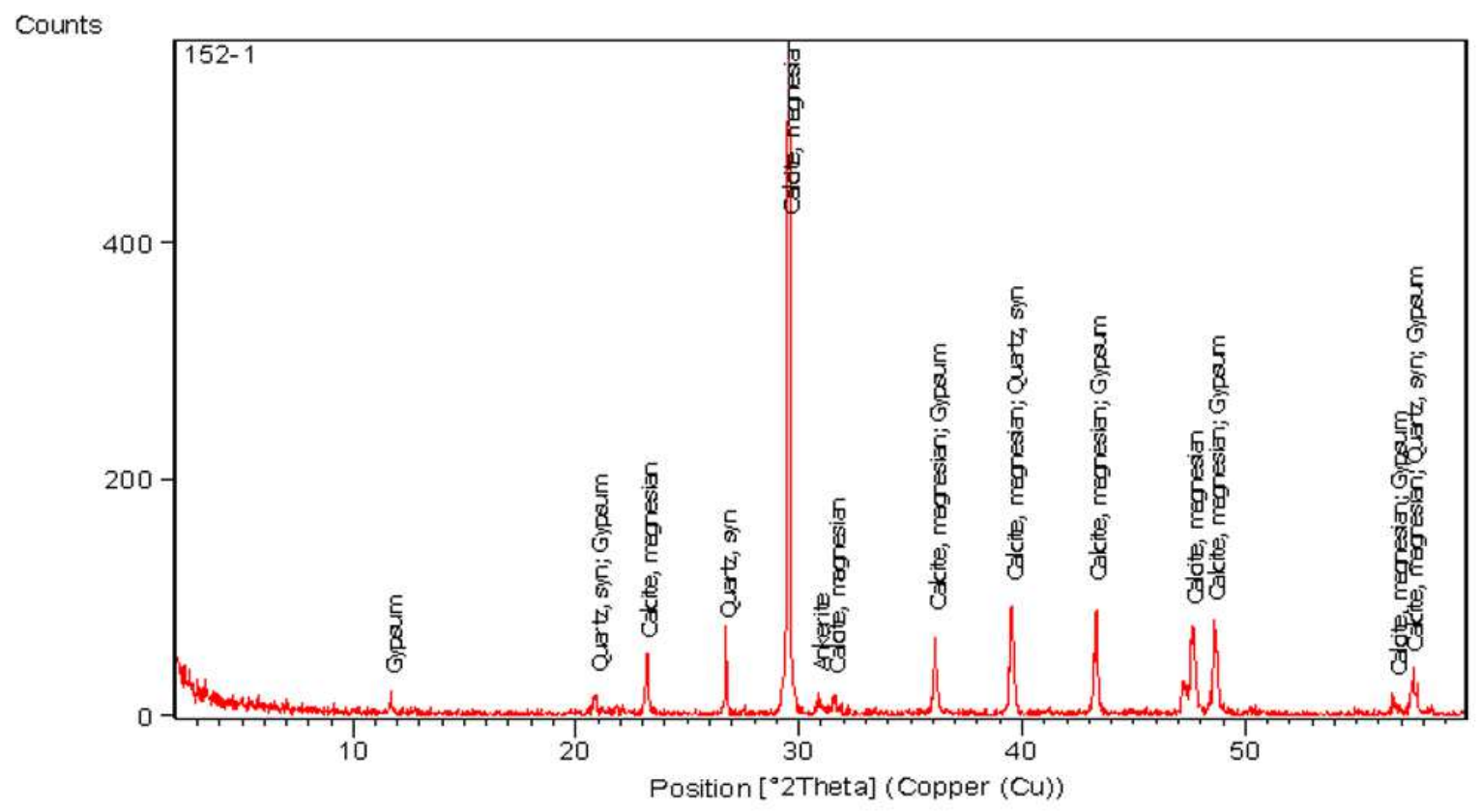

Figure.24. XRD pattern of the weathered casing limestone of the pyramid.

The Basaltic mortar have been found in fragments and mostly used for the flooring in the pyramid complex, this kind of mortar or concrete is so unique and this gives more attention for the impressive mentality of ancient Egyptians in technology of building materials. The sample have been prepared is very fine to coarse-grained, composed of numerous grains minerals (allochem) and stone fragments spread in a very fine-grained matrix. Significant amount of microfossils and fossil fragments are observed in the carbonate fragments and in the ground mass as well. Several irregular interparticle pores are detected in the sample figure 25. 


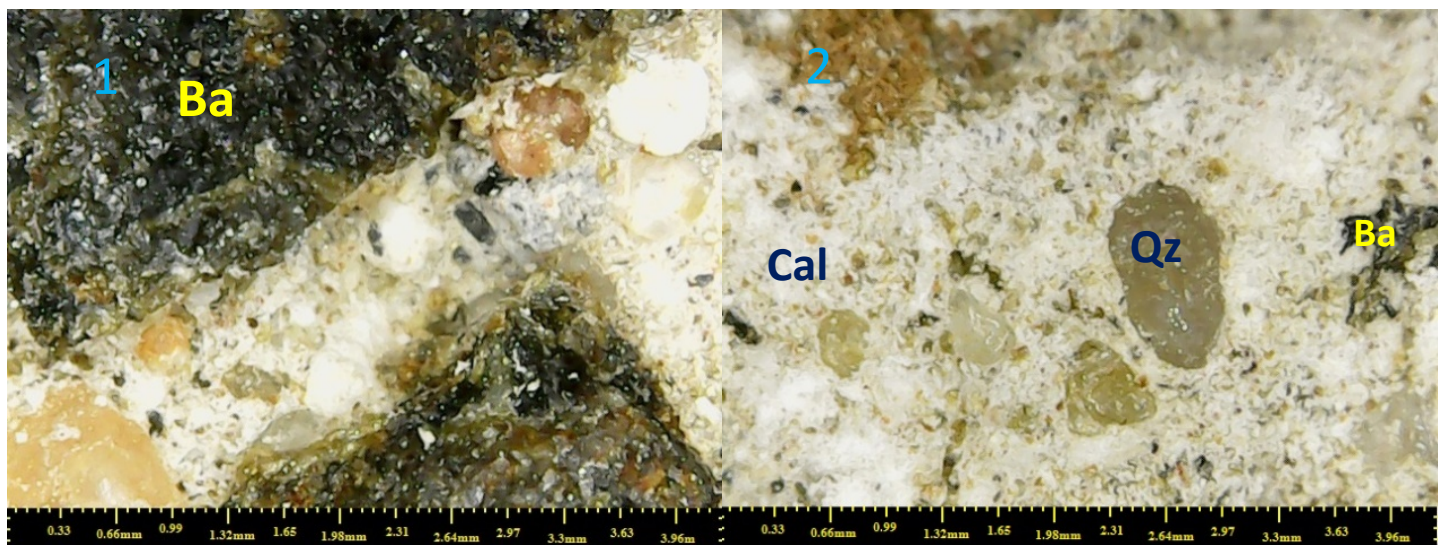

Figure.25.1,2 Archaeological Basaltic mortar, Ba(basalt), Cal(calcite) and Qz(quartz), Significant amount of microfossils and fossil fragments are observed in the carbonate fragments and in the

Petrograghically, the basaltic mortar is composed mainly of rock fragments, gravels (aggregate particles), quartz and feldspar associated with minor amounts of iron oxides, mafic minerals (mainly pyroxene \& olivine) and opaque minerals cemented by carbonate minerals admixed with gypsum, clay minerals and iron oxides. Observed stone fragments are of sedimentary (fossiliferous limestone, gypsum, feldspathic greywacke, and ironstone) and igneous (porphyritic basalt and rhyolite) origin. Rock fragments are coarse to medium-grained and have rounded to subangular outlines. Limestone fragments are the most abundant constituent. They comprise very fine to finegrained, subhedral to anhedral interlocked calcite crystals. Most of limestone is fossiliferous with microfossils of different sizes and shapes. Some of the fossils are filled by recrystallized secondary calcite figure 26. Some of limestone fragments are cut by fine microvienlets filled by recrystallized secondary calcite figure 27. Few limestone fragments have rare fine-grained quartz grains. Gypsum rock fragments are composed of a network of very fine-grained irregular gypsum crystals. This texture is characteristic for secondary gypsum after anhydrite figure28. Some gypsum fragments are dissolved leaving relics on the inner boarder of the secondary pores figure 29 .

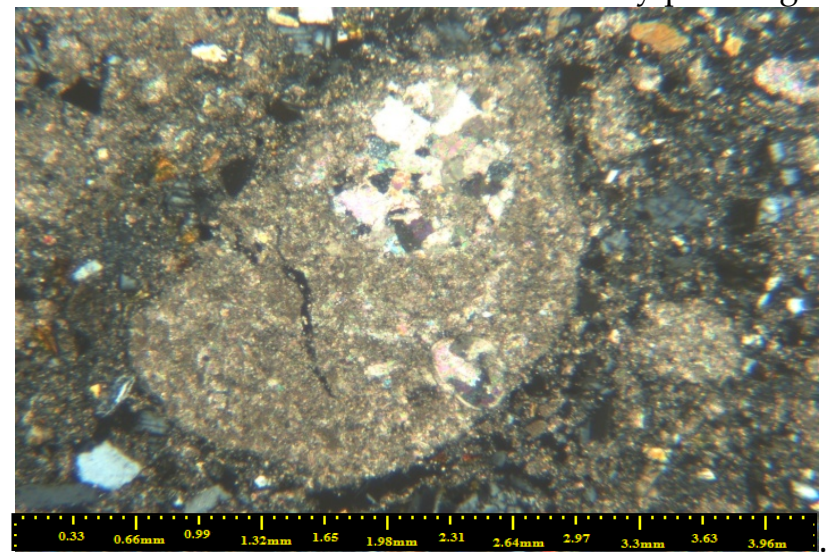

Figure.26. Observed stone fragments are of sedimentary (fossiliferous limestone, gypsum(chemical 


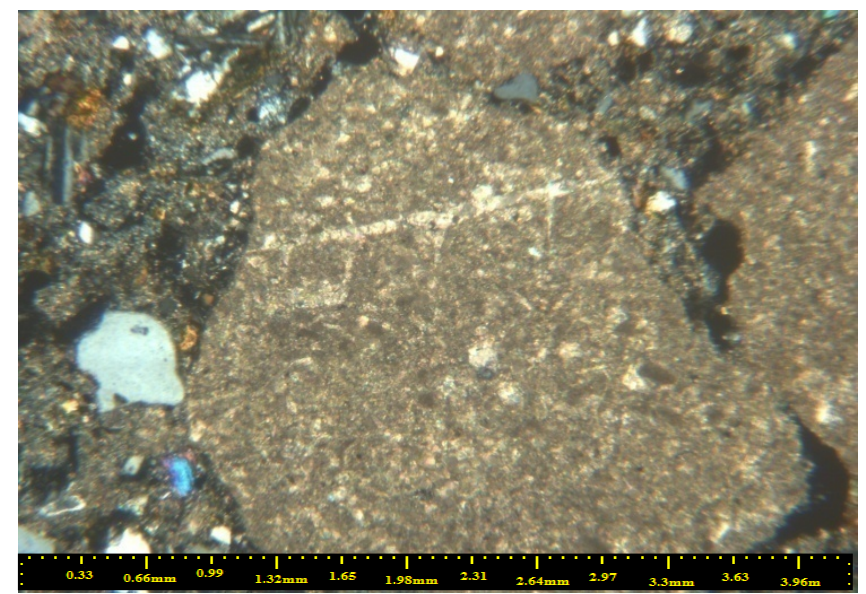

Figure.27. Some noticed limestone fragments are cut by fine microvienlets filled by recrystallized secondary calcite.

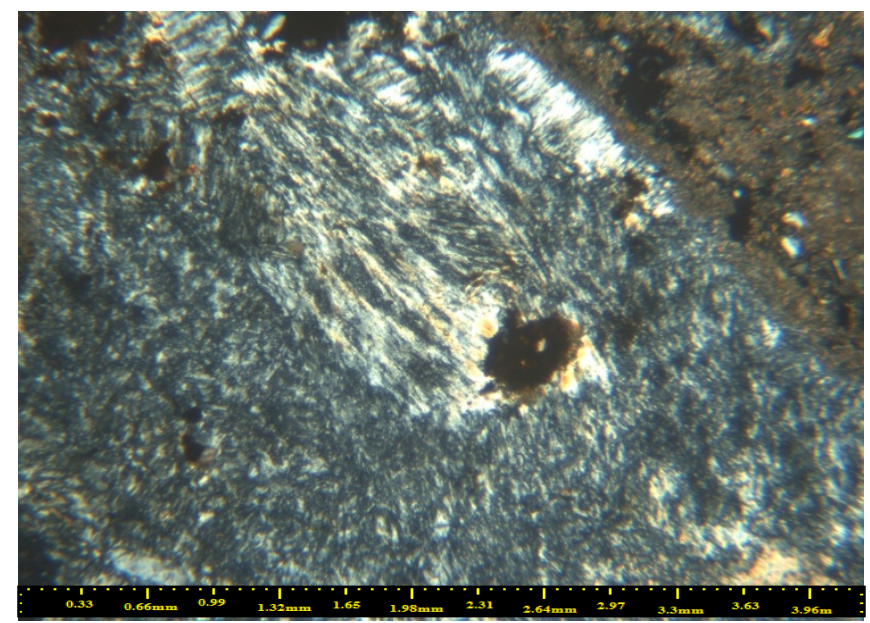

Figure.28. Gypsum rock fragments are composed of a network of very fine-grained irregular

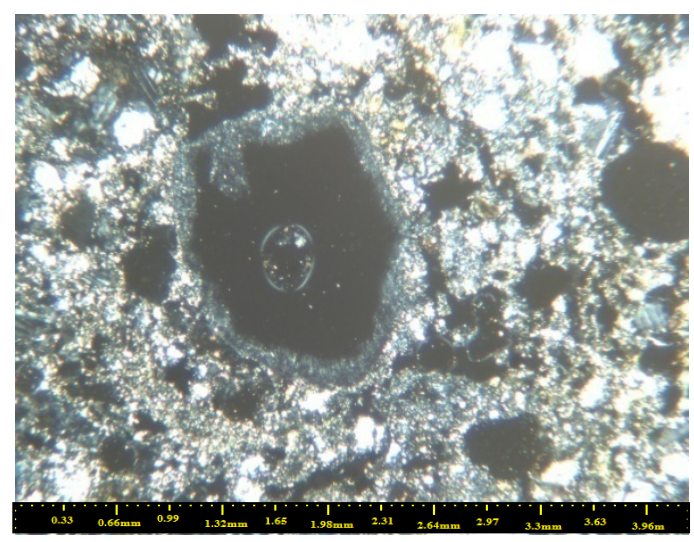

Figure.29. some gypsum fragments are dissolved leaving relics on the inner boarder of the secondary pores.

Porphyritic basalt fragments in the archaeological sample are generally composed of very fine to fine-grained plagioclase (anorthite) associated with olivine and/or pyroxene. Plagioclase in these fragments is slightly altered to sericite while olivine is highly to completely altered to iddingsite which is partially altered to limonite as well. Pyroxene is slightly altered to chlorite and iron oxides Figure 30. Feldspathic greywacke fragments comprise of very fine to fine grains of poorly sorted 
quartz (sand grains) associated with major feldspars and rare mica embedded in a very fine matrix of clay minerals and iron oxides figure31. Iron stone fragments are composed of very fine to finegrained quartz and minor calcite, embedded in a cement of iron oxides and opaque minerals. Iron stone fragments are generally porous figure 32. Rhyolite fragments are the least abundant and are composed of very fine to fine-grained quartz and potash feldspars (mainly microcline) figure 33. Potash feldspars are slightly altered to clay minerals.

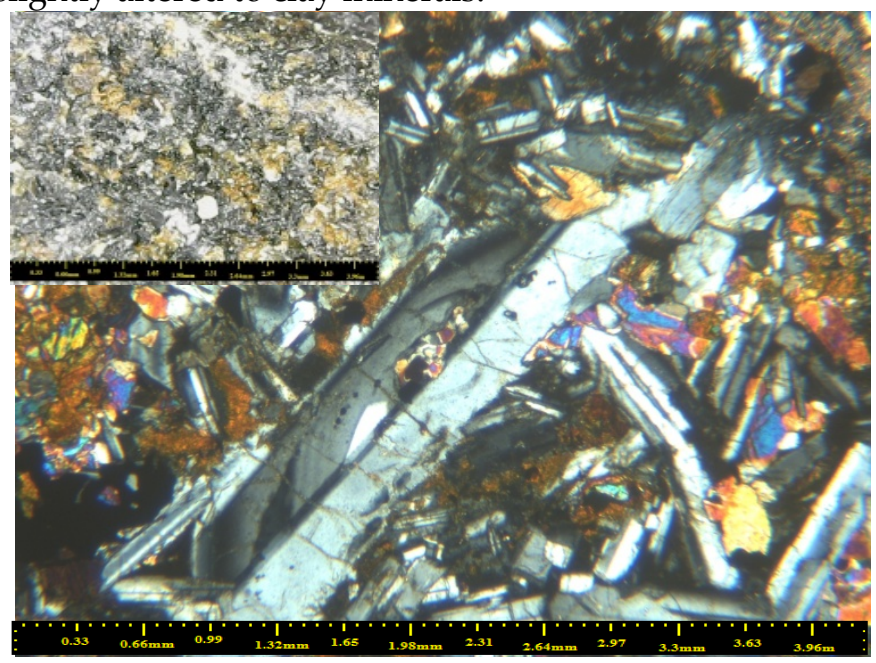

Figure.30. Alteration of basalt components, plagioclase to sericite, olivine to iddingsite, iddingsite to limonite and pyroxene to chloride and iron oxides.

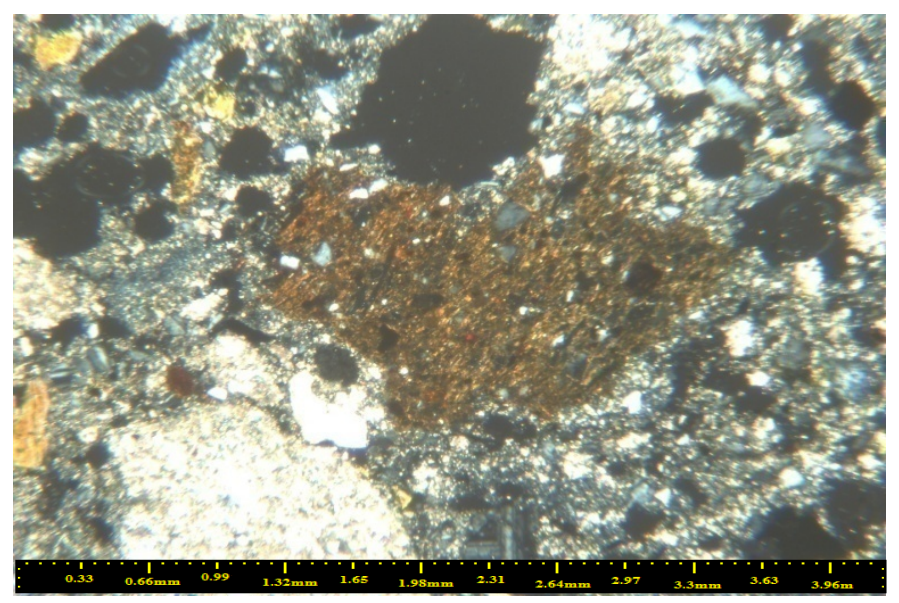

Figure.31. Feldspathic greywacke fragments with minor feldspars and rare mica embedded in a

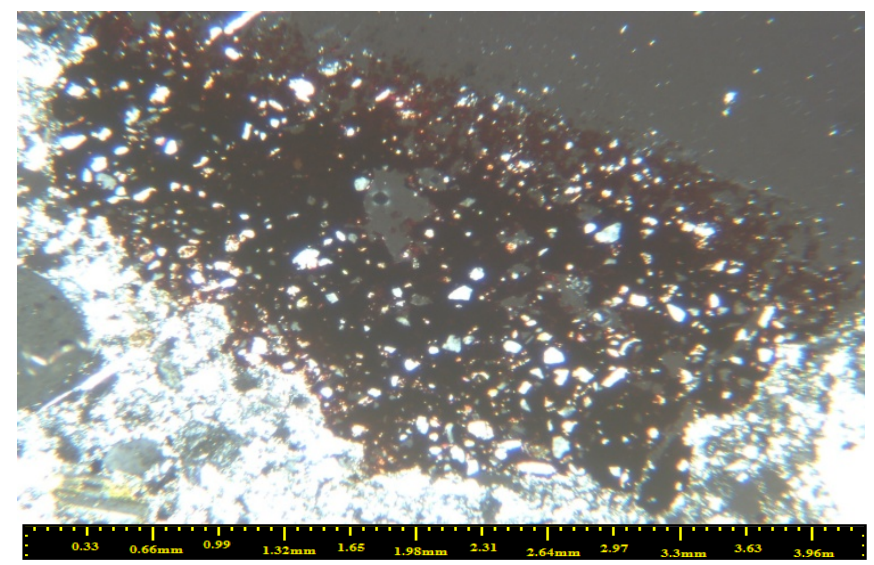


Figure.32. Iron stone fragments embedded in a cement of iron oxides and opaque minerals.

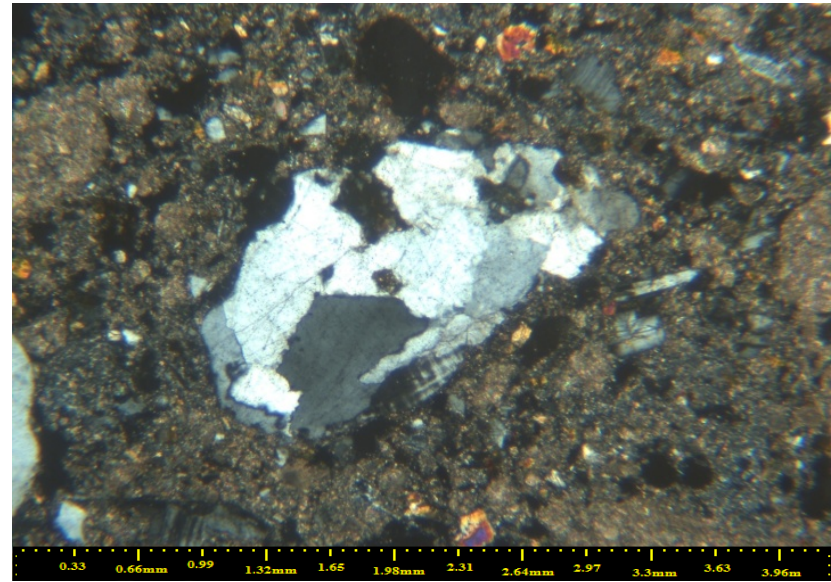

Figure.33. Rhyolite fragments are the least abundant and are composed of very fine to fine-grained quartz and potash feldspars (mainly microcline); Potash feldspars are slightly altered to clay minerals.

Free quartz grains occur as very fine to fine-grained with rounded to subangular outlines. Some grains of quartz are polycrystalline. Feldspar (anorthite) occurs as fine-grained euhedral to subhedral crystals scattered in the matrix of the sample. Calcite occurs as very fine-grained (micrite) aggregates that represents the majority of the matrix of the rock. Iron oxides and opaque minerals occur as very fine to medium-grained scattered in the sample. Mafic minerals (pyroxene \& altered olivine) present as very fine to fine-grained crystals that are observed in the matrix which reflects strong deformation of the rock fragments and the whole sample. Gypsum occurs as very finegrained, fibrous aggregates to needle-like crystals scattered in the matrix of the sample. Clay minerals occur as very fine-grained admixed with all the matrix components. Some irregular pore spaces and fine channel are detected in the sample figure 34 .

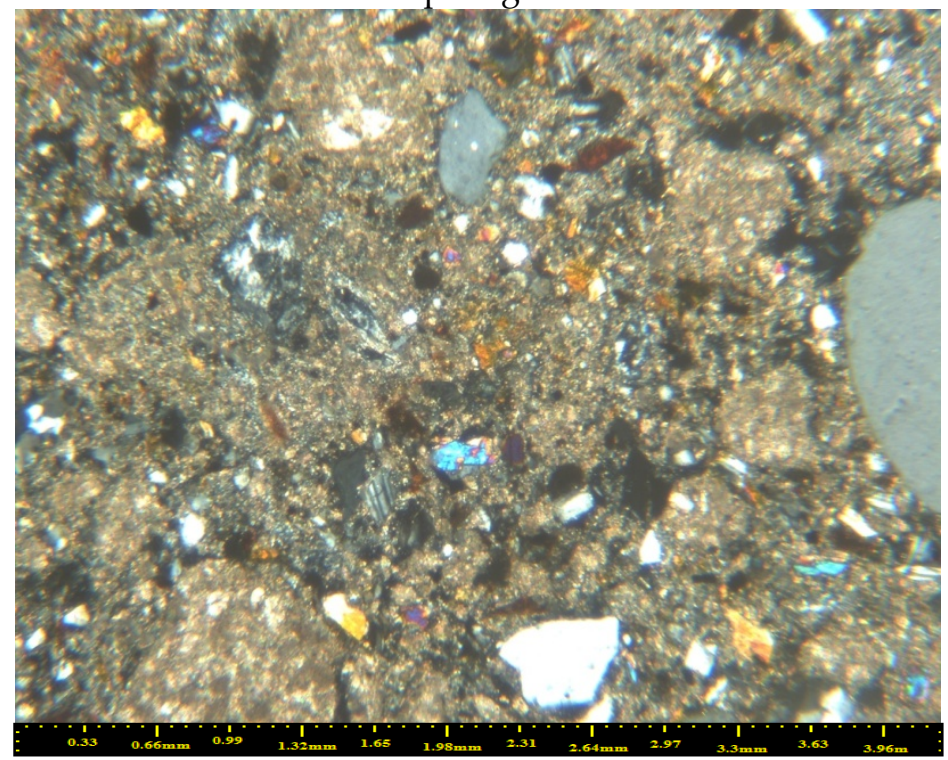

Figure.34. Some grains of quartz are polycrystalline, Feldspar (anorthite) occurs as fine-grained euhedral to subhedral crystals scattered in the matrix, Calcite occurs as very fine-grained (micrite),Iron oxides and opaque minerals occur as very fine to medium-grained, Gypsum occurs as fibrous aggregates to needle-like crystals and Some irregular pore spaces and fine channel are 
In conclusion, the sample is affected by mild alteration over essential mineral constituents. Some microfossils are filled by recrystallized secondary calcite. Some of limestone fragments are cut by fine microvienlets filled by recrystallized secondary calcite. Gypsum fragments are generally secondary after anhydrite. Some gypsum fragments are dissolved leaving relics on the inner boarder of the secondary pores. Plagioclase (in fragments and free crystals) is slightly altered to sericite while olivine (in fragments and free crystals) is highly to completely altered to iddingsite which is partially altered to limonite as well. Also, pyroxene (in fragments and free crystals) is slightly altered to chlorite and iron oxides. Potash feldspars in rock fragments are slightly altered to clay minerals.

Analytical studies had been carried out on the basaltic mortar/concrete samples by using XRD to identify the compounds and XRF to identify the major elements of the sample table 9,10 and figure 35 .

Table.9. The constituents of the basaltic mortar analyzed by XRD.

\section{Ref. Code

\begin{tabular}{|c|c|c|c|}
\hline $01-086-2335$ & Calcite, magnesium & ( Mg.064 Ca.936 ) ( C O3 ) & 40 \\
\hline $00-006-0046$ & Gypsum & Ca S O4 -2 H2 O & 30 \\
\hline $01-085-0865$ & Quartz & Si O2 & 10 \\
\hline $00-041-1486$ & Anorthite & Ca Al2 Si2 O8 & 20 \\
\hline
\end{tabular}

Table.10. Elemental analysis for the basaltic mortar to show the major elements of the sample under XRF.

\begin{tabular}{cccccccccccccc}
\hline D.N & $\mathrm{SiO} 2$ & $\mathrm{TiO} 2$ & $\mathrm{Al} 2 \mathrm{O} 3$ & $\mathrm{Fe} 2 \mathrm{O} 3$ & $\mathrm{MnO}$ & $\mathrm{MgO}$ & $\mathrm{CaO}$ & $\mathrm{Na} 2 \mathrm{O}$ & $\mathrm{K} 2 \mathrm{O}$ & $\mathrm{P} 2 \mathrm{O} 5$ & $\mathrm{Cl}$ & $\mathrm{So3}$ & Lol \\
\hline 4 & 18.80 & 0.80 & 3.79 & $\mathbf{7 . 9 3}$ & $\mathbf{0 . 1 0}$ & 0.97 & 31.19 & 0.12 & 0.90 & 0.14 & 0.40 & 16.90 & 17.50 \\
\hline
\end{tabular}




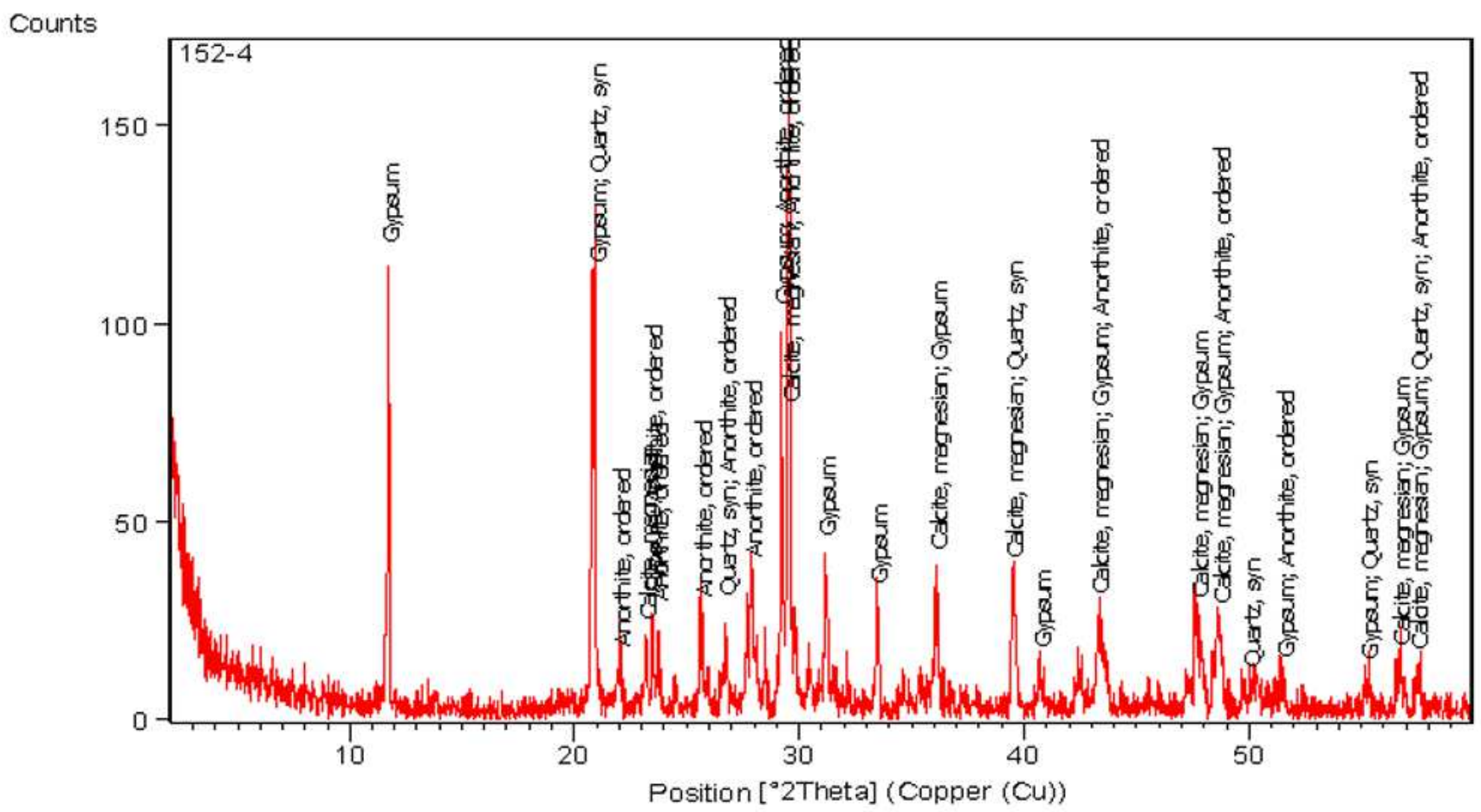

Figure.35. XRD pattern of the basaltic mortar.

\section{Physical characteristics of construction materials}

To determine the petro-physical properties such as specific gravity, apparent density, porosity nine cubic samples have been prepared form local sandy limestone at Abusir archaeological site 5 $\mathrm{cm} \times 5 \mathrm{~cm} \times 5 \mathrm{~cm}$ figures 36. The samples have been weighted naturally, after drying in $105^{\circ}$ and then the samples saturated in the water to determine the natural weight, dried weight and saturated weight table11.

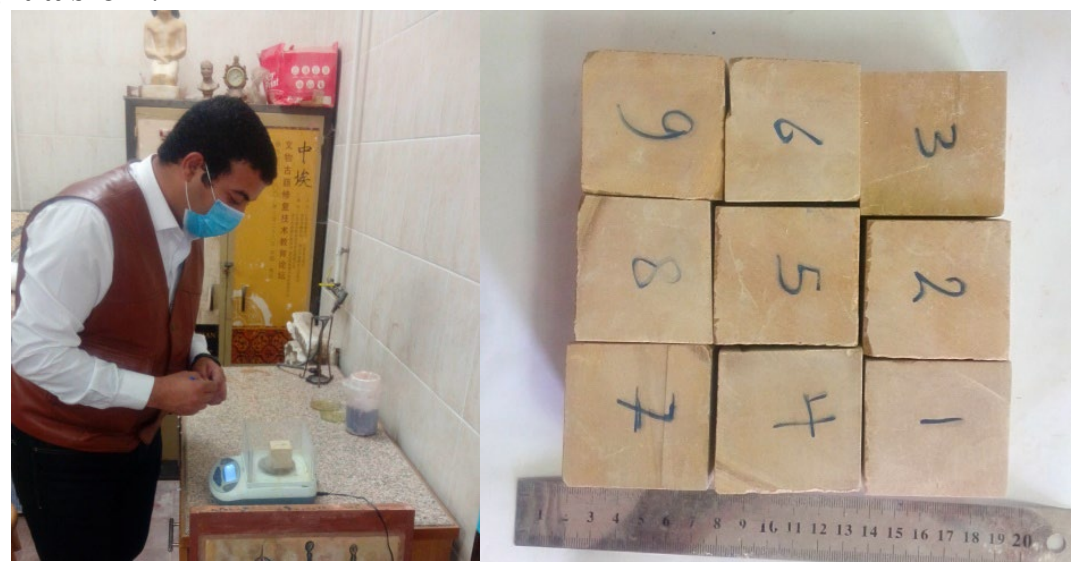

Figure.36. Preparations of the samples and measurements works for petro-physical properties for

Table.11. The natural weight, dried weight and saturated weight and some petro-physical properties for the core stone (sandy limestone) of the pyramid.

\begin{tabular}{lllllllllll}
\hline Sample No. & 1 & 2 & 3 & 4 & 5 & 6 & 7 & 8 & 9 & Average
\end{tabular}




\begin{tabular}{|c|c|c|c|c|c|c|c|c|c|c|}
\hline $\begin{array}{c}\text { Natural } \\
\text { weight(gm) }\end{array}$ & 291.8 & 307.3 & 306.3 & 319.7 & 315.2 & 297.05 & 300.3 & 302.2 & 317.3 & \\
\hline $\begin{array}{c}\text { Dried } \\
\text { weight(gm) } \\
\text { W2 }\end{array}$ & 292 & 306 & 306 & 318.5 & 314.3 & 296 & 299 & 301 & 316 & \\
\hline $\begin{array}{c}\text { Saturated } \\
\text { weight(gm) } \\
\text { W1 }\end{array}$ & 293 & 307 & 307.2 & 319.4 & 315.2 & 297 & 300 & 303 & 317.4 & \\
\hline $\begin{array}{c}\text { Water } \\
\text { absorption } \\
\text { (\%) }\end{array}$ & 0.3 & 0.3 & 0.3 & 0.2 & 0.2 & 0.3 & 0.3 & 0.7 & 0.5 & 0.3 \\
\hline W1-W2/W2 & & & & & & & & & & \\
\hline $\begin{array}{l}\text { Moisture } \\
\text { content(\%) }\end{array}$ & 0.3 & 0.3 & 0.3 & 0.2 & 0.2 & 0.3 & 0.3 & 0.7 & 0.5 & 0.3 \\
\hline W1-W2/W2 & & & & & & & & & & \\
\hline
\end{tabular}

From petro-physical measurements for the highly weathered sandy limestone, the averaged unite weight $(\gamma)$ is $2.7\left(\mathrm{~g} / \mathrm{cm}^{3}\right)$, water absorption ranged from $20 \%$ to $70 \%$, averaged density $\left(\mathrm{g} / \mathrm{m}^{3}\right) 2.7$, and averaged specific gravity(GS) is 2.7 table 12 . The main objective of petro-physical measurements is to evaluate the durability of the ancient aged stone matters. The core stone of the Sahure pyramid is highly weathered from the surrounding geo environmental conditions so the geo physical behavior of the represented samples are poor to be compatible with current state of core stone and compatible with petrological study which confirmed that there is a significant amount of microfossils and fossil fragments are observed scattered in the matrix. Some irregular pore spaces and channels are detected in the sample; some microfossils are filled by recrystallized secondary calcite and secondary quartz. The casing limestone of the pyramid is high resistant and qualified physically and mechanically but the core stone is not qualified physically and mechanically. This changes rate of properties led to much destruction for the pyramid as seen in the current state of the pyramid.

Table.12. Results of the petro-physical properties for the core stone (sandy limestone) of the pyramid.

\begin{tabular}{|c|c|c|c|c|c|c|c|c|c|}
\hline Sample No. & 1 & 2 & 3 & 4 & 5 & 6 & 7 & 8 & 9 \\
\hline $\mathrm{L}$ (length) $\mathrm{cm}$ & 5 & 5 & 4.7 & 5 & 4.9 & 4.7 & 5 & 5 & 5 \\
\hline $\mathrm{W}$ (width) cm & 5 & 4.8 & 5 & 5 & 5 & 5 & 5 & 4.8 & 5 \\
\hline $\mathrm{H}$ (height) $\mathrm{cm}$ & 4.8 & 5 & 4.7 & 5 & 5 & 5 & 5 & 5 & 5 \\
\hline $\mathrm{V}$ (Volume) $\mathrm{cm}^{3}$ & 120 & 120 & 110.5 & 125 & 122.5 & 117.5 & 125 & 120 & 125 \\
\hline $\mathrm{M}$ (mass) gm & 324 & 324 & 298.3 & 337.5 & 330.8 & 317.2 & 337.5 & 324 & 337.5 \\
\hline Weight $(\mathrm{kN})=\mathrm{Mg}$ & 3240 & 3240 & 2983 & 3375 & 3308 & 3172 & 3375 & 3240 & 3375 \\
\hline Density $(\rho) \mathrm{M} / \mathrm{V}\left(\mathrm{g} / \mathrm{m}^{3}\right)$ & 2.7 & 2.7 & 2.6 & 2.7 & 2.7 & 2.6 & 2.7 & 2.7 & 2.7 \\
\hline $\begin{array}{c}\text { UW (unit weight) }(\gamma)\left(\mathrm{g} / \mathrm{cm}^{3}\right) \\
(\rho \mathrm{g})\end{array}$ & 27 & 27 & 26 & 27 & 27 & 26 & 27 & 27 & 27 \\
\hline Specific gravity $(\mathrm{GS})=\rho / \rho_{\mathrm{w}}$ & 2.7 & 2.7 & 2.6 & 2.7 & 2.7 & 2.6 & 2.7 & 2.7 & 2.7 \\
\hline $\begin{array}{l}\text { (Absolute } \phi_{\mathrm{a}} \text { ) Total Porosity } \\
(\%) \phi \mathrm{v}_{\mathrm{v}}\left(\mathrm{w}_{1}-\mathrm{w}_{2}\right) / \mathrm{v}_{\mathrm{t}}\end{array}$ & 0.8 & 0.8 & 1 & 0.7 & 0.7 & 0.8 & 0.8 & 1.6 & 1.1 \\
\hline
\end{tabular}


Protection of Abusir archaeological site is so important to prevent the site from urban development or uncontrolled development of nearby village like Abusir village, infrastructure and tourism issues, deterioration of stones and structural problems of the building like Sahure pyramid.

Sahure pyramid has been affected by many factors of deterioration and damages for its construction materials and a lot of fallen stone blocks and fragments existed so the urgent restoration and conservation is needed to protect the pyramid. The presented research is important as it identified the construction materials used in the pyramid. In restoration of the pyramid we should use the same traditional and ancient materials of pyramid which presented in this research.

The preservation plan includes the fine restoration, structural interventions, preventive conservation and management of archaeological site of Abusir. For fine restoration; many procedures and restoration steps should be done such as cleaning for the dusts over the whole body of the pyramid partially, salts removal from the stone surfaces, consolidation of stone blocks bodies, gap filling by using improved traditional mortars such lime mortar and distinguished and integrated replacement for highly weathered blocks with new blocks from the same old quarry with same mechanical and physical properties. For structural intervention, this kind of structural repairing based on needed complicated structural analysis for the pyramid structure and the soil, in this process of preservation the authors suggested putting the falling intact blocks to its original places in inner or outer positions, designing steel or wooden supports for the inner unsafe champers and corridors, joining huge blocks by using structural pins, geotechnical study is needed and assessment for the soil problems as well.

For the site management, this process is considered one of the most important steps for the preservation of the site in indirect way. By site management, Infrastructure of Abusir will be improved such as sewage system, roads and also improving the tourism infrastructure. Currently Abusir archaeological site is ignored from tourism management although it is part of Memphis and listed as a world heritage site with all Memphis. After application of the management plan figure37, this site will be strongly a significant destination for all tourists in Egypt. Site management isn't only for infrastructure improvement and services but also the application of the strategy of preventive conservation on site scale and for the buildings.

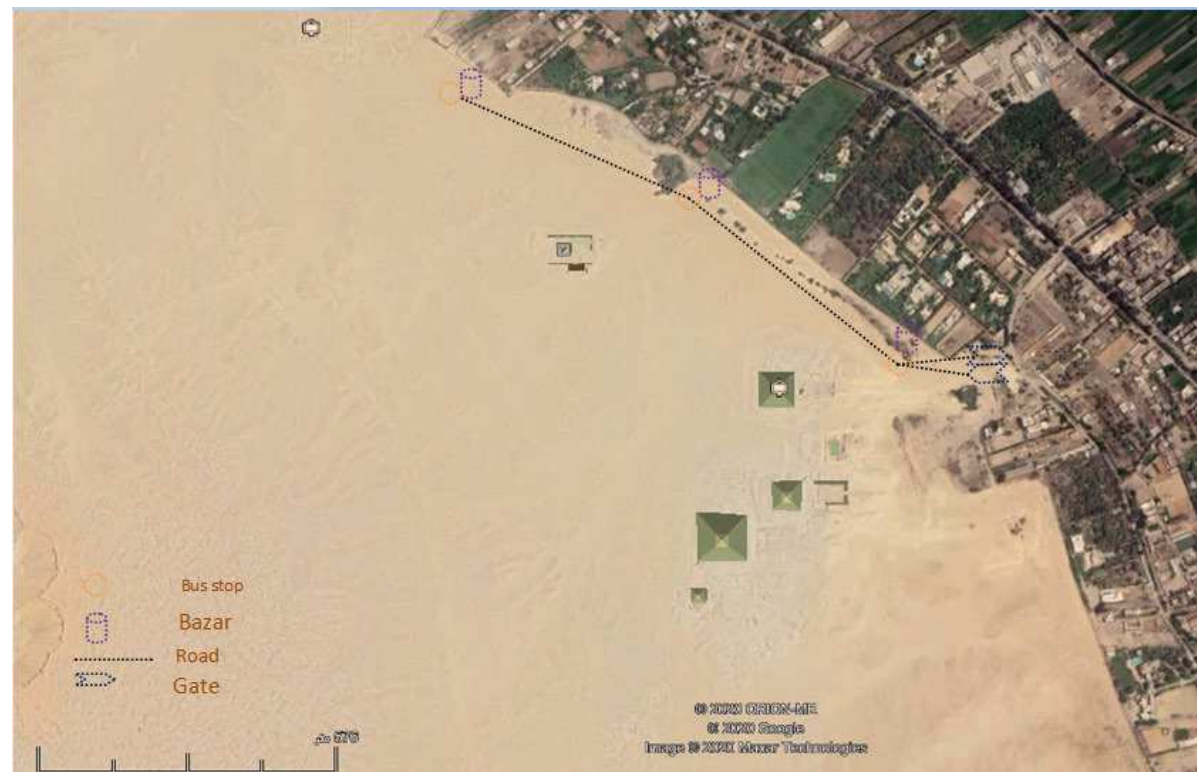

Figure.37. Google earth map shows the suggested proposal for the site management of Abusir 
This paper revealed much information for hazard analysis for the geo-environmental impacts on the Sahure pyramid at Abusir archaeological site. From field and laboratories studies the structural stability of Sahure pyramid is unsafe and more bleeding for the construction materials is coming. The geological, meteorological, geochemistry, petrological and petro-physical studies helped to understand the nature of construction materials and its durability and will contribute strongly in conservation plan for this important pyramid.

Geologically, Abusir archaeological site from Late Eocene Maadi limestone, sandy and clay limestone and marls (tafla), this geological setting has been used to be a quarry to be used and cut to prepare the core sandy limestone and also used with aggregates in joint mortars. As a result of poor quality of the geological matter the core sandy limestone have been weathered easily from the surrounding environmental factors.

Meteorically, the driest month is May with $0 \mathrm{~mm}$ of rain fall, the most precipitation falls in January. The warmest month of the year is July, with an average temperature of $27.5^{\circ} \mathrm{C}$, the difference in precipitation between the driest month and wettest month is $4 \mathrm{~mm}$ and during the year the average temperatures vary by $14.5^{\circ} \mathrm{C}$. So the fluctuations in temperature degrees, humidity and wind speed affected the archaeological construction materials tremendously. This study showed severe state of decayed surfaces of the stone construction materials (core stone and casing stone).

Analytical studies showed that the main components of the covering stone of the pyramid are calcite and ankerite and the main components of body stone of the pyramid are calcite, ankerite and quartz. For the joint mortar the paper discovered the first concrete mortar used by ancient Egyptians, fifth dynasty, this concrete/ mortar called basaltic mortar and composed of basalt, lime, quartz and rock aggregates.

This study detected of a clear and significant Anorthite mineral (plagioclase feldspar) in the mortar sample which had been proven by XRD,XRF (analysis) and Polarized light microscope (investigation), plagioclase feldspar (anorthite) occurs as fine-grained euhedral to subhedral crystals scattered in the matrix and associated with olivine and/or pyroxene.

Petrologically, internal chemical alterations of mineral composition of the core sandy limestone had been observed, those alterations plays a vital role in damaging of construction materials such as existing of ankerite which presented as alteration mineral after calcite (dolomatization process) and this reflects the yellowish color the core stone, gypsum rock fragments in joint mortars altered to appear as a network of very fine-grained irregular gypsum crystals (secondary gypsum after anhydrite) and alteration of basalt main component of basaltic mortar, plagioclase to sericite, olivine to iddingsite, iddingsite to limonite and pyroxene to chloride and iron oxides.

Petro-physically, the physical properties of the core stone is poor as a reflection to high porosity and high rate of water absorption and many channels and micro and macro cracks have been detected in the construction materials.

The main reason of the destruction of the pyramid is not only the static reasons from environmental and weathering impacts or mechanical/ dynamic actions as a result of earthquakes and wind load but also the both dynamic and static actions contributed to the damage and partial failure of the pyramid and structural studies needed for future research.

Finally, the research contributes in presenting an important study for identification of the ancient materials and their localities which used in the pyramid construction, also this study is considered as technical study for urgent needed restoration for the pyramid.

The whole database construction, investigation and analysis are presented in the manuscript had been carried out by the first author. Second author reviewed and supervised the paper. All authors read and approved the final manuscript. 
Funding

The authors confirm that he is not currently in receipt of any research funding relating to the research presented in this manuscript.

Availability of data and materials

Data sharing not applicable to this article as no datasets were generated or analyzed during the current study.

\section{Competing interests}

The authors declare that they have no competing interests.

Author details

1 Department of Earth Sciences, Faculty of Sciences, University of Cadiz, Campus Río San

\section{References}

[1] Nour Eldein, A.(2007); the Egyptian museums and archaeological sites.

[2] Miroslav, V.(2007); New Archaeological Discoveries in the Abusir Pyramid Field, Archaeogate,03-09-

2007, http://www.archaeogate.org/egittologia/article/657/1/nuove-scoperte-archeologichenellarea-dellepiramidi-di.html.

[3] Abusir L annaire du collge de France, 111,(2012); is en ligne le 22 november 2013, consulte le 22 novembre 2013, consulte le 21 mars 2020, https://doi.org/10.4000/annuaire-cdf.1799.

[4] Kawae, Y.,Yasumuro,Y. Kanaya,I. Dan, H. Chiba,F. (2016); Abusir 3D survey 2015,Czchinstitute of Egyptology, PES XVII/2016.file:///E:/ هر م20\%/papers/Abusir_3D_survey 2015.pdf.

[5] Verner, M. (2002); Abusir-The Rise of a Royal Necropolis. InAbusir: Realm of Osiris(pp. 41-68). American University in Cairo Press.Retrieved March 21, 2020, from www.jstor.org/stable/j.ctt15m7n7j.5.

[6]Czech Institute of Egyptology, Charles University in Prague, http://egyptologie.ff.cuni.cz/?req=doc:abusir\&lang=en\&11.Abusir, http://en.wikipedia.org/wiki/Abusir.

[7] K.O.Emery.(1960); Weathering of the Great Pyramid, Journal of Sedimentary Research (1960) 30 (1): 140-143, https://doi.org/10.1306/74D709DE-2B21-11D7-8648000102C1865D

[8] Hanafy.M.Holail.(1994); Diagenesis of the middle eocene "nummulite bank" of The giza pyramids plateau, Egypt: petrologic and 18o/16o evidence, Qatar Uriiv. Sci. J. (1994), 14 (I): 146-152.

[9] Franc Zalewski.(2017).Petrographic Observations of the Building Stones of the Great Pyramid of Giza, 10.17265/2328-2193/2017.04.002.

[10] Verner, M. (2001); The Pyramids: The Mystery, Culture and Science of Egypt's Great Monuments. New York: Grove Press.ISBN978-0-8021-1703-8.

[11]Verner,M.(1994); Forgotten pharaohs, lost pyramids: Abusir(PDF). Prague: Academia Škodaexport.ISBN978-80-200-0022-4.Archived fromthe original(PDF)on 2011-02-01.

[12]Lehner,M.(2008);The Complete Pyramids. New York: Thames \& Hudson.ISBN978-0-500-28547-3.

[13] Borchardt, L. (1910); Das Grabdenkmal des KönigsS'ahu-Re.Ausgrabungen der Deutschen Orient- 
of 3131

[18] Masria, A.(2017); Climate Change at Egypt.SciFed Journal of Global Warming. 1. 10.23959/sfjgw- 688 1000009.

[19] Ministry of Foreign Affairs of the Netherlands (2018) Climate Change Profile Egypt, P.O. Box 20061| 690

2500 EB, The Hague | The Netherlands, (C) Ministry of Foreign Affairs of the Netherlands | June 2018,691

17BUZ108158|E.

[20] Siegesmund,S and Snethlage,R.(2011); Stone in architecture: Properties, Durability,

[21] Comitéscientifique international "Pierre" de l'ICOMOS (2016); illustrated glossary on stone 694 deterioration patterns, ICOMOS International Scientific Committee for Stone (ISCS).

[22] Mustoe.G.(1982); Alveolar weathering. In: Beaches and costal geology. Encyclopedia of earth science, Springer. Boaton, MA.ISBN: 0-387-30843-1.

[23] Hemeda, S., Fahmy, A. and Sonbol, A (2018); Geo-Environmental and Structural Problems of the First

[24] Hemeda, S., Fahmy,A., Moustafa, A. and El Hafez, M.A. (2019); The Early Basilica Church, El- 